\title{
Electro-Oxidation in Combination with Biological Processes for Removal of Persistent Pollutants in Wastewater: A Review
}

\author{
Javier A. Navarro-Franco ${ }^{1}$, Marco A. Garzón-Zúñiga ${ }^{1 *}$, Patrick Drogui ${ }^{2}$, Gerardo Buelna ${ }^{2,3}$, \\ Pablo Gortares-Moroyoqui ${ }^{3}$, Blanca E. Barragán-Huerta ${ }^{4}$, and Juan M. Vigueras-Cortés ${ }^{1}$ \\ ${ }^{1}$ Instituto Politécnico Nacional (IPN) CIIDIR-Durango, Sigma 119 Fraccionamiento 20 de Noviembre II, Durango, Durango C.P. \\ 34220, México \\ ${ }^{2}$ Institute Nationale de Recherche Scientifique Eau Terre et Environnement (INRS-ETE) Université du Quebec, 490 rue de \\ la Couronne, Quebec, QC, Canada G1K $9 A 9$ \\ ${ }^{3}$ Instituto Tecnológico de Sonora (ITSON) 5 de Febrero 818 sur, C.P. 85000 Ciudad Obregón, Sonora, México \\ ${ }^{4}$ Instituto Politécnico Nacional Escuela Nacional de Ciencias Biológicas. Av. Wilfrido Massieu S/N, Unidad Profesional Adolfo \\ López Mateos, Ciudad de México, C.P. 07738, México
}

\begin{abstract}
Persistent organic pollutants (POPs) and emerging pollutants (EP) are characterized by their difficulty to be removed through biological oxidation processes (BOPs); they persist in the environment and could have adverse effects on the aquatic ecosystem and human health. The electro-oxidation (EO) process has been successfully used as an alternative technique to oxidize many kinds of the aforementioned pollutants in wastewater. However, the EO process has been criticized for its high energy consumption cost and its potential generation of by-products. In order to decrease these drawbacks, its combination with biological oxidation processes has been reported as a solution to reduce costs and to reach high rates of recalcitrant pollutants removal from wastewaters. Thus, the location of EO in the treatment line is an important decision to make, since this decision affects the formation of by-products and biodegradability enhancement. This paper reviews the advantages and disadvantages of $\mathrm{EO}$ as a pre and post-treatment in combination with BOPs. A perspective of the EO scaleup is also presented, where hydrodynamics and the relationship of $\mathrm{A} / \mathrm{V}$ (area of the electrode/working volume of the electrochemical cell) experiments are examined and discussed.
\end{abstract}

Keywords : Electro-Oxidation, Biological Processes, Emerging pollutants, Persistent Organic Pollutants, Hybrid Systems Received : 22 December 2020, Accepted : 6 August 2021

\section{Introduction}

Persistent organic pollutants (POPs) and emerging pollutants (EPs) in water are a serious threat to human health and ecological balance since many of them are toxic, carcinogenic and mutagenic $[1,2]$. In addition, these pollutants are highly recalcitrant and difficult to remove through Biological Oxidation Processes (BOPs). Ttherefore, conventional wastewater treatment plants (WWTPs) are recognized as the main sources of POPs and EPs in the environment [3-5].

*E-mail address: mgarzon@ipn.mx

DOI: https://doi.org/10.33961/jecst.2020.01746

This is an open-access article distributed under the terms of the Creative Commons Attribution Non-Commercial License (http://creativecommons.org/licenses/by-nc/4.0) which permits unrestricted non-commercial use, distribution, and reproduction in any medium, provided the original work is properly cited.
In response, several advanced oxidation processes (AOPs) have been introduced, such as Electro-oxidation (EO), UV, ozonation $\left(\mathrm{O}_{3}\right)$, Fenton, $\mathrm{UV} / \mathrm{H}_{2} \mathrm{O}_{2}$, $\mathrm{UV} / \mathrm{O}_{3}, \mathrm{UV} / \mathrm{H}_{2} \mathrm{O}_{2} / \mathrm{O}_{3}$, and $\mathrm{UV} / \mathrm{TiO}_{2}[6,7]$.

Of the above, EO is the most studied process due to its several advantages such as: environmental compatibility, versatility, energy efficacy, amenability to automation, and high efficacy in destroying POPs and EPs in water, wastewater and sludge $[2,8]$. EO has been studied along with several effluents, most notably: tannery [9], electrical industry [10], coke production [11], dyes [12] and hospitals [13]. However, the EO process has been criticized for: (1) its high operating costs related to electricity consumption, (2) its potential to form by-products more toxic than the originals, (3) some effluents may require the addition of supporting electrolytes which elevate 
operating costs and (4) short life of electrodes, due to deposits of organic material on their surface (passivation/fouling) $[14,15]$. These disadvantages can be reduced if EO is combined with BOPs, which are cheaper to operate and work well with biodegradable organic matter, nutrients and solids (components that interfere with EO performance). In this sense, EO can be combined with BOPs as pre-treatment or posttreatment [2]. Studies from the 1980s already suggested this combination in order to make EO affordable [16]. For instance, Wang et al. [11] reduced the cost of water treatment from coke production from 116 to $64 \mathrm{kWh} / \mathrm{kg}$ COD, when coupling a biofilter to an EO process. However, decision making criteria on where to locate EO in a coupled system is not entirely clear.

This review aims at understanding the potential benefits and drawbacks of different systems combining EO and BOPs, either conventional (e.g. activated sludge) or novel technologies (e.g. organic bed biofiltration); and how they affect the formation of by-products. Additionally, it takes a look at the advances in the scale-up process, its challenges and recommendations for future research.

\subsection{Content of POPs and EPs in different kind of waters}

The concentration of some POPs and EPs in different types of water are shown in Table 1. The presence of these pollutants encompasses all types of matrices, from rivers and lakes to influents and effluents from WWTPs. The concentrations of these contaminants in water vary widely, ranging from a few ng/L to several thousand $\mu \mathrm{g} / \mathrm{L}$.

Pawlak et al. [17] found a total concentration of PAHs of $6212 \mathrm{ng} / \mathrm{L}$ in a lake located in the Polish Polar Station, Horsund in Svalbard, Norway, being naphthalene the most important one with $5530 \mathrm{ng} / \mathrm{L}$; Chen et al. [20] evaluated 10 PAHs in several rivers in the Hangzhou region, in China, an area with industrial antecedents, and found concentrations of between $0.989 \mu \mathrm{g} / \mathrm{L}$ and up to $9.663 \mu \mathrm{g} / \mathrm{L}$; Olayinka et al. [28] determined the total PAHs in the bay of Lagos, Nigeria, which ranged from 46 to $507 \mu \mathrm{g} / \mathrm{L}$ with the highest presence of Pyrene $(22-92 \mu \mathrm{g} / \mathrm{L})$, fluoranthene (9-140 $\mu \mathrm{g} / \mathrm{L}$ ) and Phenanthrene (3$139 \mu \mathrm{g} / \mathrm{L})$. There is a number of sources of PAHs and their concentration can be due to oil spills, atmo-

Table 1. Content of some POPs and EPs in water and wastewater

\begin{tabular}{|c|c|c|c|c|}
\hline Pollutant & Concentration & Units & Matrix & Ref. \\
\hline \multicolumn{5}{|c|}{ Polycyclic aromatic hydrocarbon (PAH) } \\
\hline \multirow{3}{*}{ Naphthalene } & 5530 & $\mathrm{ng} / \mathrm{L}$ & Lake & {$[17]$} \\
\hline & 0.047 & $\mathrm{mg} / \mathrm{L}$ & Effluent WWTP & [18] \\
\hline & 0.254 & $\mathrm{mg} / \mathrm{L}$ & Effluent WWTP (Stabilization ponds) & {$[18]$} \\
\hline \multirow{2}{*}{ Fluorene } & 111 & $\mathrm{ng} / \mathrm{L}$ & WWTP with denitrification zone & {$[19]$} \\
\hline & 2218 & $\mu \mathrm{g} / \mathrm{L}$ & River & {$[20]$} \\
\hline \multirow{2}{*}{ Phenanthrene } & 3154 & $\mu \mathrm{g} / \mathrm{L}$ & River & {$[20]$} \\
\hline & 0.126 & $\mathrm{mg} / \mathrm{L}$ & River & {$[18]$} \\
\hline \multirow{2}{*}{ Anthracene } & $1.78-2.12$ & $\mathrm{ng} / \mathrm{L}$ & WWTP with denitrification zone & {$[19]$} \\
\hline & 0.169 & $\mu \mathrm{g} / \mathrm{mL}$ & WWTP stabilization ponds & {$[21]$} \\
\hline \multirow{2}{*}{ Acenaphthene } & $3-408$ & $\mathrm{ng} / \mathrm{L}$ & WWTP with denitrification zone & {$[19]$} \\
\hline & 0.579 & $\mathrm{mg} / \mathrm{L}$ & River & {$[18]$} \\
\hline \multirow{2}{*}{ Pyrene } & 8 & $\mathrm{ng} / \mathrm{L}$ & WWTP with denitrification zone & {$[19]$} \\
\hline & 1.348 & $\mu \mathrm{g} / \mathrm{L}$ & River & {$[20]$} \\
\hline \multirow{4}{*}{ Benzo(a)pyrene } & 0.168 & $\mu \mathrm{g} / \mathrm{L}$ & River & {$[20]$} \\
\hline & 0.086 & $\mu \mathrm{g} / \mathrm{mL}$ & WWTP stabilization ponds & {$[21]$} \\
\hline & 0.077 & $\mu \mathrm{g} / \mathrm{mL}$ & WWTP trickling filter-activated sludge & {$[21]$} \\
\hline & 0.090 & $\mu \mathrm{g} / \mathrm{mL}$ & WWTP rotating biological contractors with extended aeration & {$[21]$} \\
\hline
\end{tabular}


Table 1. Content of some POPs and EPs in water and wastewater

\begin{tabular}{|c|c|c|c|c|}
\hline Pollutant & Concentration & Units & Matrix & Ref. \\
\hline \multicolumn{5}{|l|}{ Organochlorinated pesticides } \\
\hline Pyrethroid & 0.013 & $\mu \mathrm{g} / \mathrm{L}$ & Wastewater effluents, Agricultural activities & {$[22]$} \\
\hline DDT & $0.069-0.84$ & $\mu \mathrm{g} / \mathrm{L}$ & Wastewater effluents, Agricultural activities & {$[23,24]$} \\
\hline Aldrin & 10 & $\mathrm{ng} / \mathrm{L}$ & WWTP Activated Sludge & [24] \\
\hline \multicolumn{5}{|l|}{ Pharmaceutical compounds } \\
\hline Hydrochlorothiazide & 91 & $\mathrm{ng} / \mathrm{L}$ & WWTP Activated sludge (anaerobic, anoxic, aerobic) & [25] \\
\hline \multirow{2}{*}{ Carbamazepine } & 244 & $\mathrm{ng} / \mathrm{L}$ & WWTP Oxidation ditch-Effluent after UV disinfection & {$[25]$} \\
\hline & 1850 & $\mathrm{ng} / \mathrm{L}$ & Influent WWTP & {$[26]$} \\
\hline Meprobamate & 6.27 & $\mathrm{ng} / \mathrm{L}$ & WWTP Activated sludge (anaerobic, anoxic, aerobic) & {$[25]$} \\
\hline Metformin & 57.6 & $\mathrm{ng} / \mathrm{L}$ & WWTP Oxidation ditch-Effluent after UV disinfection & [27] \\
\hline Diclofenac & 3250 & $\mathrm{ng} / \mathrm{L}$ & Influent WWTP & {$[26]$} \\
\hline Bezafibrate & 1550 & $\mathrm{ng} / \mathrm{L}$ & Influent WWTP & {$[26]$} \\
\hline Iopromide & 3840 & $\mathrm{ng} / \mathrm{L}$ & Influent WWTP & {$[26]$} \\
\hline Sulfamethoazole & 1106 & $\mathrm{ng} / \mathrm{L}$ & Influent WWTP & {$[26]$} \\
\hline \multicolumn{5}{|c|}{ Personal care products (PCPs) } \\
\hline \multirow{2}{*}{ Galaxolide } & $1110-4020$ & $\mathrm{ng} / \mathrm{L}$ & WWTP with denitrification zone & [19] \\
\hline & 830 & $\mathrm{ng} / \mathrm{L}$ & Influent WWTP & {$[26]$} \\
\hline \multirow{2}{*}{ Tonalide } & $240-1020$ & $\mathrm{ng} / \mathrm{L}$ & WWTP with denitrification zone & [19] \\
\hline & 450 & $\mathrm{ng} / \mathrm{L}$ & Influent WWTP & {$[26]$} \\
\hline Antibacterial/Triclosan & 755 & $\mathrm{ng} / \mathrm{L}$ & WWTP with denitrification zone & [19] \\
\hline
\end{tabular}

spheric deposition, wastewater discharge, soil entrainment, and oil infiltration [28,29]. According to the guidelines of the World Health Organization [30], contamination by PAHs is reached at a concentration of above $50 \mathrm{ng} / \mathrm{L}$ as an individual component, which is relatively easy to achieve (Table 1). Other POPs have been even more restrictive with the maximum limit recommendations such as Benzo(a)pyrene, which should not exceed $0.7 \mu \mathrm{g} / \mathrm{L}$ in drinking water, because it is the most carcinogenic of all PAHs [30].

This is worrisome because the concentration of Benzo(a)pyrene in wastewater can be as high as $90 \mu \mathrm{g} / \mathrm{L}$. In rivers, values of up to $0.168 \mu \mathrm{g} / \mathrm{L}$ have been recorded [20].

\subsection{Contribution of biological oxidation process for POPs and EPs removal}

The removal of pollutants in a biological process depends mainly on microorganisms, the biodegradability and physicochemical characteristics of the pollutant, temperature, redox conditions, the availability of a substrate, among others [31]. Therefore, removal rates for the same pollutant may greatly vary in literature; even more with recalcitrant ones (Table 2). For example, Biel-Maeso et al. [19] obtained similar efficiencies in a denitrification treatment system for naphthalene, fluorene, anthracene and pyrene with 50, 42, 45 and 54\%, respectively. Gao et al. [32] used rot-fungus Pseudotrametes gibbosa to remove anthracene and pyrene, reporting removal efficiencies of 46 and $24 \%$, respectively. Treatment with algae has also proven not to be efficient for EPs removal; de Wilt et al. [33] used inoculated Chlorella sorokiniana in urine and treated wastewater enriched with carbamazepine, trimethoprim and diclofenac, for which they reported a removal of 30, 40 and up to $60 \%$, respectively. Of the above, carbamazepine is a highly stable drug that is difficult to degrade even under activated sludge acclimatization conditions. In this regard, Wang and Wang [34] acclimated acti- 
Table 2. Treatment of POPs and EPs using biological treatment

\begin{tabular}{|c|c|c|c|c|}
\hline Matrix & $\begin{array}{l}\text { Biorecalcitrant } \\
\text { pollutant }\end{array}$ & $\begin{array}{l}\text { Biological process and } \\
\text { operating conditions }\end{array}$ & $\begin{array}{c}\text { Main Results } \\
\text { Pollutant removal efficiency }\end{array}$ & Ref. \\
\hline $\begin{array}{l}\text { Urine, anaerobically } \\
\text { treated black water and } \\
\text { synthetic urine }\end{array}$ & $\begin{array}{l}\text { Pharmaceutical } \\
\text { compounds }\end{array}$ & $\begin{array}{l}\text { C. sorokiniana CCAP211/8K } \\
\text { Batch experiments. } \\
\text { The flasks were filled with } 300 \mathrm{~mL} \\
\text { medium, inoculated with } 1.66 \times 10^{5} \mathrm{cell} / \\
\text { ml C. sorokiniana, spiking of micropol- } \\
\text { lutants was necessary to obtain suffi- } \\
\text { cient LC- MS response }(>100 \text { times } \\
\text { higher than the limit of quantification) }\end{array}$ & $\begin{array}{l}\text { Removal efficiencies: } \\
\text { Chlorella sorokiniana } \\
\text { Diclofenac (40-60\%), } \\
\text { carbamazepine (30\%), } \\
\text { trimethoprim }(40 \%)\end{array}$ & [33] \\
\hline Synthetic wastewater & $\begin{array}{l}\text { Pharmaceutical } \\
\text { compounds }\end{array}$ & $\begin{array}{c}\text { Flow: } 0.5 \mathrm{~mL} / \mathrm{min} \\
\text { HRT/SRT (days) } 1.38 \\
\text { DO }(2.07 \mathrm{mg} / \mathrm{L} \pm 0.6) \\
\text { SCOD mg/L }(592 \pm 78) \\
\text { Organic loading } 426.24 \mathrm{mg} / \text { Days }\end{array}$ & $\begin{array}{c}\text { Removal efficiencies of } \\
\text { Bezafibrate }(35.1 \pm 1 \%), \\
\text { gemfibrozil }(41 \pm 18 \%) \text {, } \\
\text { Indomethacin }(35 \pm 12 \%) \text { and } \\
\text { sulfamethoxazole }(48 \pm 23 \%)\end{array}$ & [35] \\
\hline Synthetic wastewater: & $\begin{array}{l}\text { Polycyclic aromatic } \\
\text { hydrocarbon }(\mathrm{PAH}) / \\
\text { phenanthrene } \\
\text { and Tween }{ }^{\circledR} 80\end{array}$ & $\begin{array}{c}\text { Aerobic biological reactor } \\
\text { with activated sludge. Operation: }>2.5 \\
\mathrm{mg} \mathrm{O}_{2} / \mathrm{L} ; \text { Nutrients and sucrose were } \\
\text { added for acclimation; } \mathrm{pH} 6.5-7.5 ; 300 \\
\text { rpm; COD:N:P }>100: 5: 1 ; 0.35 \pm 0.05 \mathrm{~g} \\
\text { VSS/L; Initial concentration of: } 1.31 \mathrm{~g} \\
\text { TW80/L and } 25 \mathrm{mg} \\
\text { Phenanthrene } / \mathrm{L}\end{array}$ & $\begin{array}{l}\text { Total degradation of both } \\
\text { phenanthrene and Tween }{ }^{\circledR} 80 \\
\text { Removal of COD }(44 \%)\end{array}$ & [36] \\
\hline Industrial wastewater & Dyes & $\begin{array}{l}\text { Zero-valent iron and coagulation) } \\
\text { and UASB (up-flow anaerobic sludge } \\
\text { blanket) }\end{array}$ & $\begin{array}{c}\text { COD was decreased about } 7000 \\
\mathrm{mg} / \mathrm{L} \text { to } 532 \mathrm{mg} / \mathrm{L} ; \\
\text { Biologically-pretreated } \\
\text { effluent presented } 27 \% \\
\text { inhibition ratio of luminescence }\end{array}$ & [12] \\
\hline Synthetic & $\begin{array}{l}\text { Polycyclic aromatic } \\
\text { hydrocarbon }(\mathrm{PAH}) / \\
\text { anthracene and pyrene }\end{array}$ & $\begin{array}{l}\text { Rot-fungus Pseudotrametes } \\
\text { gibbosa in northern China. } \\
\text { The culture conditions were } 25^{\circ} \mathrm{C}, \\
130 \mathrm{r} / \mathrm{min} \text {, and a degradation period of } \\
21 \text { days, with the degradation } \\
\text { efficiency determined every } 7 \text { days. }\end{array}$ & $\begin{array}{l}\text { The degradation of } \\
\text { anthracene and pyrene } \\
\text { by aboriginal white } \\
\text { rot-fungus P. gibbosa were } 43 \\
\text { and } 26 \% \text {, respectively. }\end{array}$ & [32] \\
\hline Municipal wastewater & $\begin{array}{l}\text { Polycyclic aromatic } \\
\text { hydrocarbon (PAH) }\end{array}$ & WWTP with denitrification zone & $\begin{array}{l}\text { Removals for phenanthrene, } \\
\text { Naphthalene, Fluorene, } \\
\text { Anthracene and Pyrene were } \\
50,42,45 \text { and } 54 \%, \\
\text { respectively }\end{array}$ & [19] \\
\hline Municipal wastewater & $\begin{array}{l}\text { Personal care } \\
\text { products (PCPs) }\end{array}$ & WWTP with denitrification zone & $\begin{array}{c}\text { Removals for Galaxolide, } \\
\text { Tonalide, Antibacterial/TCS, } \\
\text { were } 31,-13 \text {, and } 43 \%, \\
\text { respectively }\end{array}$ & [19] \\
\hline Municipal wastewater & $\begin{array}{l}\text { Personal care } \\
\text { products (PCPs) }\end{array}$ & WWTP & $\begin{array}{l}\text { Removals for Galaxolide, } \\
\text { Tonalide, were } 35.5, \\
\text { and } 64 \% \text {, respectively }\end{array}$ & [26] \\
\hline
\end{tabular}

vated sludge biomass to different initial carbamazepine concentrations $(0.2,1,5,10$ and $15 \mathrm{mg} / \mathrm{L})$ and reached a $22.8 \%$ removal efficiency (Table 2 ).

In general, if recalcitrant pollutants are well removed through biological treatments, it is achieved through sorption and not biodegradation [31] (Fig. 1). Therefore, the contribution of BOPs to the removal of recalcitrant pollutants (POPs and EPs) is variable and frequently poor, finding higher concentrations in the effluent than in its corresponding influent, on occasions. 

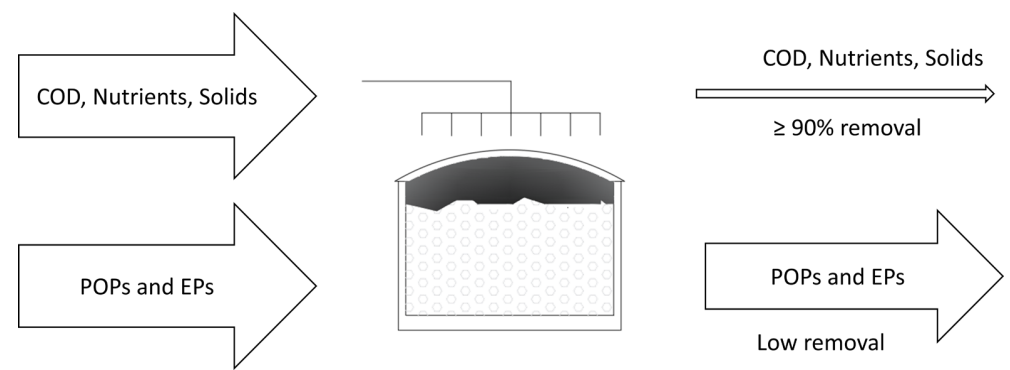

Fig. 1. Biological Oxidation Process (BOP).
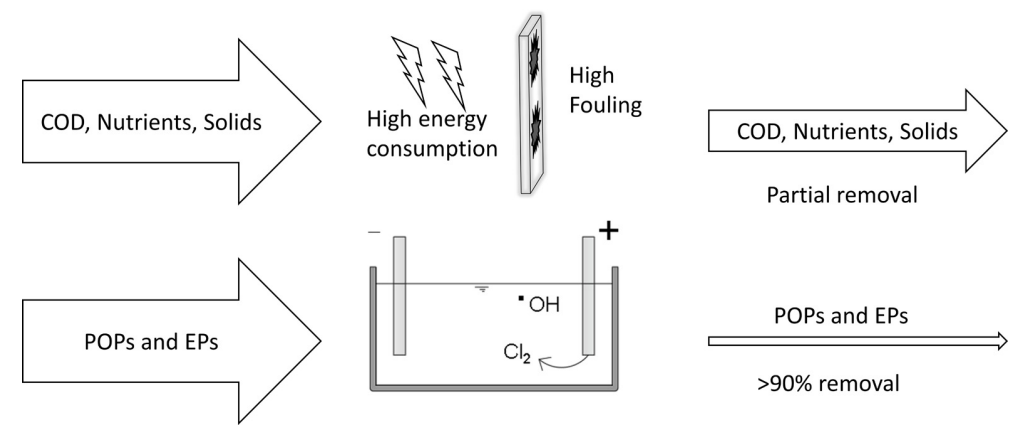

Fig. 2. Electrooxidation process (EO).

\section{Contribution of electro-oxidation process for POPs removal}

EO is an alternative to a conventional wastewater treatment to remove the most recalcitrant organic pollutants from complex effluents or to transform them into biodegradable compounds by breaking or fragmenting them until their mineralization or conversion into more easily biodegradable by-products $[6,37]$. This process occurs in an electrochemical reactor called electrolytic cell, which is composed by a tank, an electrolyte (that could be the same wastewater to be treated), a pair of electrodes, an anode (where the pollutants are expected to be oxidized), a cathode (where commonly heavy metals can be reduced but also organic matter) and a power source (Fig. 2). This process relies on oxidation-reduction reactions that occur in the electrolytic cell to depurate waste effluents [2]. Pollutants can be removed in an EO process following direct and/or indirect oxidation.

Direct oxidation takes place in two stages: (1) the diffusion of the pollutants from the solution to the anode surface and (2) the oxidation of the pollutants on the surface of the anode by direct electron transfer (Fig. 3). Hydroxyl radicals $(\bullet \mathrm{OH})$ are formed by the anodic oxidation of water and physiosorbed at the electrode's surface [6,38].

Indirect oxidation occurs when a mediator $(\mathrm{HClO}$, $\mathrm{HBrO}, \mathrm{H}_{2} \mathrm{O}_{2}, \mathrm{H}_{2} \mathrm{~S}_{2} \mathrm{O}_{8}$ ) is electrogenerated to carry out the oxidation of pollutants [6]. By-products are formed due to the presence of chloride in wastewater which is oxidized into chlorine $\left(\mathrm{Cl}_{2}\right)$ at the anode. Then chlorine reacts with water to form hypochlorous acid $(\mathrm{HClO})$. This compound can react with organic matter and amines to produce trihalomethanes (THMs) and chloramines, respectively (Fig. 3). The resulting synergy could be highly effective in the degradation of many pollutants. Nevertheless, it has the drawback of toxicity (discussed later) [38].

Side reactions could also occur when the current density applied to the EO process is high enough to overcome the oxidation potential of the anode. In this case, oxygen will be produced instead of $\bullet \mathrm{OH}$, thus decreasing the efficacy of the oxidation process. To avoid this, "non-active" electrodes (most commonly $\mathrm{BDD}$ and $\mathrm{PbO}_{2}$ ) are required to generate the hydroxyl radicals (called "active oxygen" physiosorbed), which in turn assist with the non-selective oxidation of organic compounds, resulting in their total oxidation to $\mathrm{CO}_{2}[38,39]$. The electrodes consid- 


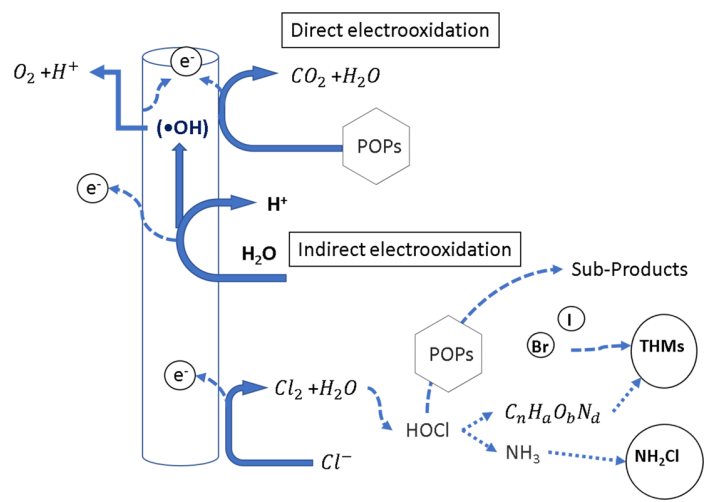

Fig. 3. Conceptual representation of direct and indirect electro-oxidation, as well as the formation of chlorine byproducts

ered "Active" such as $\mathrm{Pt}, \mathrm{IrO}_{2}, \mathrm{RuO}_{2}, \mathrm{SnO}_{2}$ and $\mathrm{SbO}_{2}$ show low levels of mineralization attributed mainly to a highly active behavior, i.e., low production of -OH $[14,40,41]$.

Due to the simplicity of EO, its application has been evaluated in all kinds of industrial effluents such as: tannery [9], electrical industry [10], coke production [42], dyes [12], landfill leachate [39], olive pomace leachate [43]; and also for other purposes, e.g. disinfection of urban stormwater and secondary effluents [44-46], removal of EPs from hospital effluents [13], among others.

\subsection{Advantages and limitations of EO as a single treatment system}

Among all AOPs, EO is the most frequently used to remove organic pollutants from a wide diversity of effluents [47]. There is an extensive list of literature related to EO and its application in complex effluents [48-51], and there is also a generalized consensus on their following advantages:

Short retention time. It is possible to apply EOP over short periods of time, mostly of between 60 to $120 \mathrm{~min}$, which translate into small space requirements. However, retention time depends on several factors, namely: complexity of the effluent, water quality requirements, current density/intensity applied and the material of the electrode [8,52,53].

Ease of operation/automation. EO is characterized to be a simple technology, easy to operate and to adapt to an existing biological/ physicochemical process or even to replace it $[6,14]$.

No chemicals. The only consumable is electricity, i.e., it does not require equipment for the addition of chemicals [6,14].

However, EO shows disadvantages when compared to conventional biological processes, such as: the relative high cost associated with energy consumption and the generation of dangerous by-products [54]. Additionally, other possible limitations for EO will be covered along this section.

Although there are several reasons to choose EO as the main treatment to remove recalcitrant pollutants, there are also several factors that must be taken into account which affect its performance:

$\boldsymbol{p H}$. It is an important parameter that affects the indirect oxidation mainly. In the reactions mediated by chlorine $\left(\mathrm{Cl}^{-}\right)$, the $\mathrm{pH}$ value will affect the proportion of hypochlorous acid $(\mathrm{HClO})$ and hypochlorite $\left(\mathrm{ClO}^{-}\right)$. Acidic conditions would be desired since chlorine gas $\left(\mathrm{Cl}_{2}\right)$ is the strongest oxidant followed by $\mathrm{HClO}$ and $\mathrm{ClO}^{-}$.

Side reactions. The formation of $\bullet \mathrm{OH}$ occurs at potentials well below the onset of oxygen evolution. The formation of oxygen instead of $\bullet \mathrm{OH}$ depends mainly on the electrode material which has a specific oxygen evolution potential. If this is high, the formation of $\bullet \mathrm{OH}$ increases and the formation of oxygen decreases. Oxygen formation, a side or secondary reaction, ends in low current efficiencies for complete mineralization [38], since $\bullet \mathrm{OH}$ transforms into oxygen before interacting with any other organic molecule (equation 1 and 2):

$$
\begin{aligned}
& M[\bullet \mathrm{OH}]+R \rightarrow \mathrm{MO}+\mathrm{CO}_{2}+\mathrm{H}_{2} \mathrm{O}+\mathrm{H}^{+}+e^{-} \\
& \mathrm{MO} \rightarrow \mathrm{M}+\frac{1}{2} \mathrm{O}_{2}+\mathrm{H}^{+}+e^{-}
\end{aligned}
$$

\section{$\mathrm{M}=$ electrode}

$\mathrm{R}=\mathrm{POP}$

$\mathrm{MO}=$ higher oxide or superoxide

Passivation or corrosion of the electrodes. It is one of the main problems of the EO in wastewater treatment. Fouling of the electrodes is caused by oligomeric or polymeric material deposited on the surface of the electrode, which causes its deactivation and affects durability $[38,55]$. Passivation is a type of impermeable layer that builds on the surface of the 
electrode during its interaction with the pollutant. This layer decreases the transfer rate of electrons between the pollutants and the anode surface and therefore limits the efficiency of the process. For example, Liu et al. [56] investigated the electrode fouling process during EO for water spike with phenol $(2 \mathrm{mmol} / \mathrm{L})$. The polymeric layer decreased the electrochemically active surface area of the electrode from $8.38 \mathrm{~cm}^{2}$ to $1.57 \mathrm{~cm}^{2}$ and was developed in barely $100 \mathrm{~min}$ of electrolysis $(2.0 \mathrm{mmol} / \mathrm{L}$ phenol in $0.1 \mathrm{~mol} / \mathrm{L} \mathrm{NaCl}$ at $1.0 \mathrm{~V}$ vs SHE).

However, some studies agree that the best antifouling strategy is to oxidize the polymeric layer by applying high potentials close to the water discharge region [56-58]. At anode potentials above $2.7 \mathrm{~V}$ vs SHE, anions such as chlorine can mitigate electrode fouling by preventing the formation of the polymer layer by active chlorine $\left(\bullet \mathrm{Cl}\right.$ and $\left.\mathrm{Cl}_{2}\right)$ [56].

For instance, Panizza et al. [58] when treating naphthalene sulfonates, found that working with high potentials removed the polymeric film from the anode.

Unfortunately, the higher the current, the greater the deterioration of the electrodes [14,59]. This is especially worrying for electrodes such as $\mathrm{PbO}_{2}$ since, despite being very efficient and relatively cheap to manufacture, they are also not very stable [40] are short-lived and its application may be limited by a possible release of toxic lead ions [48].

High treatment costs. It has been repeatedly proven that EO is not currently applicable at a full scale due to its high implementation cost at pilot and full scales; costly manufacture of electrodes, high consumption of electrical energy by mass of organic matter removed and, at a pilot scale, hydrogen generation makes the operation of the EO complex [39].

Mineralization. Another reason for using EO is the attractive mineralization that is achieved by subjecting the pollutants in close contact with $\bullet \mathrm{OH}$ and other electro-generated oxidative species. However, it could take a long time to almost mineralize the organic compound. Giraldo et al. [60] could not mineralize oxacillin even after a long exposure time (8 h). In addition, in the vast majority of studies, a complete mineralization is never achieved as revealed by the measurement of total organic carbon or by the detection of by-products of the concern pollutant.

The use of EO as pre-treatment involves dealing with a raw effluent, which could contain high amounts of organic matter, solids, color, turbidity, toxic compounds, among others. All of these factors being able to affect the performance of the $\mathrm{EO}$ in the degradation process (Fig. 3).

\section{Coupling EO with BOPs}

The EO's main advantage, over other conventional wastewater treatment processes is the conversion of organic compounds into simpler ones and, in theory, up to a final mineralization to $\mathrm{CO}_{2}$ and $\mathrm{H}_{2} \mathrm{O}$, which would make the addition of a following treatment module unnecessary. In addition, EO (or any other AOPs) results in the only alternative when the BOPs are not able to deliver the desired quality effluent, e.g., in the treatment of leachates [39]. However, since industrial and/or domestic wastewater effluents are often complex matrices that require long retention times and therefore high energy consumption, in the EO process, in order to reach mineralization levels, its widespread use in real scenarios is greatly restricted [2]. It has been concluded then that if this technology is not complemented with a renewable energy source, it is unlikely to be applied as a sole treatment [41]. Nevertheless, there is an alternative: the coupling of EO with BOPs (Table 3) with the main objective of combining the biological degradation of the organic matter with the potential of the EO to oxidize POPs and to degrade organic matter hardly biodegradable until its mineralization in relatively short times [14] (Fig. 4). As already mentioned in the introduction, this option was proposed since the 80 s, but now this line of research has gained interest because the regulatory guidelines are becoming stricter; the pressure on water resources is increasing and the vigilance of the authorities to enforce discharge limits is growing. The following section examines and discusses the advantages and disadvantages of coupling an EO process with a biological treatment, both as a pre-treatment and post-treatment, as well as the role of the oxidizing species such as those derived from chlorine.

\subsection{EO as pre-treatment}

3.1.1 Electrogenerated by-products

Garcia-Segura et al. [2] says that the configuration of a hybrid electrochemical/biological system will depend mainly on the amount of chlorine and other oxidizing species and the requirements of the treated water. 
Table 3. Studies about coupled electro-oxidation to a biological process

\begin{tabular}{|c|c|c|c|c|c|}
\hline Ref. & $\begin{array}{l}\text { Wastewater } \\
\text { origin }\end{array}$ & $\begin{array}{c}\text { Characterization of } \\
\text { wastewater }\end{array}$ & $\begin{array}{l}\text { Biological treatment and } \\
\text { operation conditions }\end{array}$ & $\begin{array}{l}\text { Electro-oxidation process } \\
\text { operation conditions }\end{array}$ & Main results \\
\hline [11] & $\begin{array}{l}\text { Coking } \\
\text { wastewater }\end{array}$ & $\begin{array}{c}\mathrm{BOD}_{5}(\mathrm{mg} / \mathrm{L}): 10.28-15.23 ; \text { Volatile } \\
\text { phenol }(\mathrm{mg} / \mathrm{L}): 0.56-0.78 ; \text { cyanide } \\
(\mathrm{mg} / \mathrm{L}): 2.52-3.80 ; \mathrm{NH}_{4}^{+}(\mathrm{mg} / \mathrm{L}): \\
56.2-7.6 ; \mathrm{N}^{-} \mathrm{NO}_{3}^{-}(\mathrm{mg} / \mathrm{L}): \\
\text { 21.12-29.38; conductivity }(\mu \mathrm{S} / \mathrm{cm}): \\
\text { 1850-1920; pH: } 7.2-7.9\end{array}$ & $\begin{array}{l}\text { Biological aerated filter: Diameter: } \\
10 \mathrm{~cm} \text {; height: } 1.0 \mathrm{~m} ; \\
\text { packing material: Lava } 0.5 \mathrm{~cm} \\
\text { diameter; hydraulic retention time } \\
\text { (HRT): } 13.08 \mathrm{~h}, 8.72 \mathrm{~h} \text {, and } 6.54 \mathrm{~h}\end{array}$ & $\begin{array}{l}\text { Anode: BDD; area electrodes: } \\
50.7 \mathrm{~cm}^{2} \text {; electrode gap: } 10 \mathrm{~mm} \text {; } \\
\text { volume: } 3 \mathrm{~L} \text {; current applied: } 75 \mathrm{~mA} / \mathrm{cm}^{2} \text {; } \\
\text { electrolysis time: } 45 \mathrm{~min}\end{array}$ & 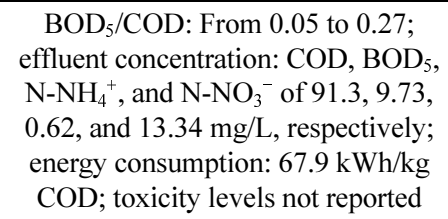 \\
\hline [61] & $\begin{array}{l}\text { Landfill } \\
\text { leachate }\end{array}$ & $\begin{array}{c}\mathrm{COD}(\mathrm{mg} / \mathrm{L}): 13,700 ; \mathrm{NH}_{4}^{+}(\mathrm{mg} / \mathrm{L}) \\
\text { 1880; } \mathrm{N}^{-N_{3}}(\mathrm{mg} / \mathrm{L}): 21.12-29.38 \\
\text { conductivity }(\mu \mathrm{S} / \mathrm{cm}): 17400 ; \mathrm{pH}: 7.5 ; \\
\text { chloride }(\mathrm{mg} / \mathrm{L}): 2500 ; \text { solids }(\mathrm{mg} / \mathrm{L}): \\
\text { 950; note: characterization } \\
\text { of pretreated leached by BOPs }\end{array}$ & Not reported & $\begin{array}{l}\text { Anode: BDD; area electrodes: } 70 \mathrm{~cm}^{2} \text {; } \\
\text { electrode gap: } 5 \text { and } 1 \mathrm{~mm} \text {; volume: } \\
2 \text { and } 750 \mathrm{~L} \text {; current applied: } \\
45 \mathrm{~mA} / \mathrm{cm}^{2} \text {; electrolysis time: } 480 \mathrm{~min}\end{array}$ & $\begin{array}{l}\text { Dilutions } 1: 8 \text { and } 1: 16 \text { and after } 6 \mathrm{~h} \\
\text { of treatment present values below the } \\
\text { Portuguese legal discharge COD limit }\end{array}$ \\
\hline [62] & $\begin{array}{l}\text { Landfill } \\
\text { leachate }\end{array}$ & $\begin{array}{l}\mathrm{COD}(\mathrm{mg} / \mathrm{L}): 6500-8000 ; \mathrm{BOD}_{5} \\
(\mathrm{mg} / \mathrm{L}): 540-800 ; \mathrm{NH}_{4}{ }^{+}(\mathrm{mg} / \mathrm{L}): \\
\text { 1250-1720; solids }(\mathrm{mg} / \mathrm{L}): \\
650-800 ; \text { conductivity }(\mu \mathrm{S} / \mathrm{cm}): \\
\text { 29000-31000; pH: 7.7-8.5; } \\
\text { chloride }(\mathrm{mg} / \mathrm{L}): 6000-7000\end{array}$ & $\begin{array}{l}\text { Volume: } 20 \mathrm{~L} \text {; membrane: } 400 \mathrm{~mm} \\
\text { length, } 30 \mathrm{~mm} \text { diameter, } \\
0.04 \mathrm{~m}^{2} \text { surface; } \\
\text { note: Previous acclimation } \\
\text { was needed }\end{array}$ & $\begin{array}{l}\text { Anode: } \mathrm{DSA}^{\circledR} \text {; area electrodes: } 60 \mathrm{~cm}^{2} \text {; } \\
\text { electrode gap: } 25 \mathrm{~mm} \text {; volume: } 0.95 \mathrm{~L} \text {; } \\
\text { current applied: } 4 \mathrm{~A} / \mathrm{dm}^{2} ; \\
\text { electrolysis time: } 60 \mathrm{~min}\end{array}$ & $\begin{array}{c}\text { Best conditions: } \mathrm{t}=1 \mathrm{~h}, \mathrm{~J}=4 \mathrm{~A} / \mathrm{dm}^{2} \\
\left(400 \mathrm{~mA} / \mathrm{cm}^{2}\right), \text { Ti/Pt electrode; COD } \\
(85 \%), \mathrm{NH}_{4}^{+}(94 \%) \text {. Energy consumption } \\
\text { reduce from } 127 \mathrm{kWh} / \mathrm{kg} \text { COD }(\mathrm{EO}) \text { to } \\
\quad 60 \mathrm{kWh} / \mathrm{kg} \mathrm{COD}(\mathrm{MBR} / \mathrm{EO})\end{array}$ \\
\hline [63] & $\begin{array}{l}\text { Landfill } \\
\text { leachate }\end{array}$ & $\begin{array}{c}\mathrm{COD}(\mathrm{mg} / \mathrm{L}): 15000 ; \mathrm{NH}_{4}{ }^{+}(\mathrm{mg} / \mathrm{L}): \\
\text { 2913; conductivity }(\mu \mathrm{S} / \mathrm{cm}): \\
\text { 29000-31000; } \mathrm{pH}: 8.39 \\
\text { chloride }(\mathrm{mg} / \mathrm{L}): 3800\end{array}$ & $\begin{array}{l}\text { Anoxic/aerobic oxidation } \\
\text { and Ultra filtration }\end{array}$ & $\begin{array}{c}\text { Anode: } \mathrm{BDD}, \mathrm{Pt}, \mathrm{Ti} / \mathrm{PtO}_{2}-\mathrm{IrO}_{2} \\
\mathrm{Ti} / \mathrm{RuO}_{2}-\mathrm{TiO}_{2}, \mathrm{Ti} / \mathrm{RuO}_{2}-\mathrm{IrO}_{2} \\
\text { and } \mathrm{Ti}_{2} / \mathrm{IrO}_{2}-\mathrm{Ta}_{2} \mathrm{O}_{5} ; \text { area electrodes: } \\
84 \mathrm{~cm}^{2} ; \text { electrode gap: } 5 \text { and } 1 \mathrm{~mm} ; \\
\text { volume: } 2 \text { and } 750 \mathrm{~L} ; \text { current applied: } \\
\text { 6-36 mA } / \mathrm{cm}^{2} ; \\
\text { electrolysis time: } 0-240 \mathrm{~min}\end{array}$ & $\begin{array}{l}\text { BDD anode effluent concentration } \\
\text { from } 888.1 \text { to } 70.8 \mathrm{mg} / \mathrm{L} \\
\left(92 \% \text { removal) with } 36 \mathrm{~mA} / \mathrm{cm}^{2}\right. \\
\text { and } 360 \mathrm{~min} \text { and energy consumption } \\
321.3 \mathrm{kWh} / \mathrm{kg} \mathrm{COD}\end{array}$ \\
\hline [10] & $\begin{array}{l}\text { Electronics } \\
\text { industry }\end{array}$ & $\begin{array}{c}\mathrm{COD}(\mathrm{mg} / \mathrm{L}): 116-1348 \\
\mathrm{BOD}_{5}(\mathrm{mg} / \mathrm{L}): 36-445 ; \mathrm{NH}_{4}^{+}(\mathrm{mg} / \mathrm{L}): \\
\text { 10.48-0.86; solids }(\mathrm{mg} / \mathrm{L}): 650-800 \\
\text { conductivity }(\mu \mathrm{S} / \mathrm{cm}): 2100-419 ; \\
\text { pH: } 3.5-7.8 ; \\
\text { chloride }(\mathrm{mg} / \mathrm{L}): 1.66-4.01\end{array}$ & $\begin{array}{l}\text { Biological Membrane. } \\
\text { Operation conditions are not specified }\end{array}$ & $\begin{array}{l}\text { Anode: carbon PTFE cloth and BDD; } \\
\text { Area electrodes: } 80 \mathrm{~cm}^{2} \text {; electrode gap: } \\
30 \mathrm{~mm} \text {; Volume: } 0.4 \mathrm{~L} \text {; Current } \\
\text { applied: } 45 \mathrm{~mA} / \mathrm{cm}^{2} \text {; Electrolysis time: } \\
30 \mathrm{~min} \text {; Note: Prior experiments elec- } \\
\text { trolyte was saturated with } \mathrm{O}_{2}\end{array}$ & $\begin{array}{l}37 \mathrm{kWh} / \mathrm{g} \text { TOC; after } 30 \mathrm{~min} \text { the } \\
\text { formation of formaldehyde, } \\
\text { a by-product from the formic acid } \\
\text { generation, increased } \mathrm{BOD}_{5} / \mathrm{COD} \\
\text { from } 0.3 \text { to } 0.7\end{array}$ \\
\hline [13] & $\begin{array}{l}\text { Hospital } \\
\text { wastewater }\end{array}$ & Synthetic biodegradable water & $\begin{array}{l}\text { MBR; hydraulic retention time: } 18 \mathrm{~h} \text {; } \\
\text { solid retention time: } 140 \mathrm{~d} ; \\
\text { Biomass: } 16.5 \mathrm{~g} / \mathrm{L}\end{array}$ & $\begin{array}{l}\text { Anode: } \mathrm{DSA}^{\circledR} \text {; area electrodes: } 60 \mathrm{~cm}^{2} \text {; } \\
\text { electrode gap: } 25 \mathrm{~mm} \text {; volume: } 0.95 \mathrm{~L} \text {; } \\
\text { current applied: } 0.5-2 \mathrm{~A} \text {; electrolysis } \\
\text { time: } 40 \mathrm{~min}\end{array}$ & $\begin{array}{l}\text { Best results when EO as post-treatment } \\
\text { and effluent not toxic to Daphnia } \\
\text { magna } 100 \% \mathrm{v} / \mathrm{v} \text {. Also, higher } \\
\text { efficiencies were met for } \\
\text { carbamazepine and venlafaxine } \\
(\sim 97 \%)\end{array}$ \\
\hline
\end{tabular}


Table 3. Continued

\begin{tabular}{|c|c|c|c|c|c|}
\hline Ref. & $\begin{array}{c}\text { Wastewater } \\
\text { origin }\end{array}$ & $\begin{array}{c}\text { Characterization of } \\
\text { wastewater }\end{array}$ & $\begin{array}{l}\text { Biological treatment and } \\
\text { operation conditions }\end{array}$ & $\begin{array}{c}\text { Electro-oxidation process } \\
\text { operation conditions }\end{array}$ & Main results \\
\hline [49] & $\begin{array}{l}\text { Industrial } \\
\text { wastewater } \\
\text { containing 5- } \\
\text { amino-6- } \\
\text { methyl-2-ben- } \\
\text { zimidazolone } \\
\text { (AMBI) }\end{array}$ & $\begin{array}{c}\text { AMBI (\% TOC): } 94 ; \text { TOC }(\mathrm{mg} \mathrm{C} / \mathrm{L}) \\
\text { BOD }_{5}: 136 \mathrm{mg} / \mathrm{L} ; \\
\text { COD: } 14350 \mathrm{mg} / \mathrm{L} ; \text { conductivity: } \\
15.8(\mathrm{mS} / \mathrm{cm}) ; \mathrm{Cl}: 7335 \mathrm{mg} / \mathrm{L} \\
\mathrm{NH}_{4}^{+}: 6.8 \mathrm{mg} / \mathrm{L} \\
\mathrm{PO}_{4}{ }^{3+}: 0.9 \mathrm{mg} / \mathrm{L} ; \mathrm{pH}: 6.3\end{array}$ & $\begin{array}{l}\text { Fixed bed reactor (FBR) Vol: } 1 \mathrm{~L} \text {; } \\
\text { flow rate: } 6 \mathrm{~L} / \mathrm{h}(100 \mathrm{~mL} / \mathrm{min}) \\
\text { pH: } 7 \text {; aeration flow: } 150 \mathrm{~L} / \mathrm{h}\end{array}$ & $\begin{array}{l}\text { Anode: Pt; cathode: zirconium spiral; } \\
\quad \text { electrolytic cell: } \\
\quad \mathrm{L} \times \mathrm{B} \times \mathrm{H}=0.6 \mathrm{~m} \times 0.6 \mathrm{~m} \times 1.5 \mathrm{~m} \text {; } \\
\text { area electrodes: } 40 \mathrm{~cm}^{2} \text {; electrode gap: } \\
1 \mathrm{~cm} \text {; volume: } 150 \mathrm{~mL} \text {; current applied: } \\
2 \mathrm{~A}\left(50 \mathrm{~mA} / \mathrm{cm}^{2}\right) \text {; temperature: } 70^{\circ} \mathrm{C}\end{array}$ & $\begin{array}{l}\text { Global toxicity EO/FBR: } \\
\text { Non-biodegradability, } \\
\text { test Zahn-Wellens }\end{array}$ \\
\hline [40] & $\begin{array}{l}\text { WWTP } \\
\text { Effluent }\end{array}$ & $\begin{array}{l}\mathrm{COD}(\mathrm{mg} / \mathrm{L}): 27 ; \text { TOC }(\mathrm{mg} / \mathrm{L}): 8.4 \\
\mathrm{NO}_{3}^{-}(\mathrm{mg} / \mathrm{L}): 37 ; \text { solids }(\mathrm{mg} / \mathrm{L}): 650- \\
\text { 800; conductivity }(\mu \mathrm{S} / \mathrm{cm}): 820 ; \mathrm{pH}: 8 \\
\text { chloride }(\mathrm{mg} / \mathrm{L}): 172 ; 17 \alpha \text {-ethinyl } \\
\quad \text { estradiol }(\mu \mathrm{g} / \mathrm{L}): 100-800\end{array}$ & Not reported & $\begin{array}{l}\text { Anode: BDD; area electrodes: } 19 \mathrm{~cm}^{2} \text {; } \\
\text { electrode gap: no reported; volume: } \\
115 \mathrm{~mL} \text {; current applied: } 0.9-2.6 \mathrm{~mA} / \\
\mathrm{cm}^{2} \text {; electrolysis time: } 1.5-30 \mathrm{~min}\end{array}$ & $\begin{array}{l}\text { Adding } 0.1 \mathrm{~mol} / \mathrm{L} \text { of } \mathrm{NaCl} \text { as support, } \\
\text { the removal of ethinyl estradiol was } \\
\text { carried out in less than } 1 \mathrm{~min} \text {, also } \\
\text { reducing costs due to the decrease of } \\
\text { the applied potential by } 50 \% \text {. } \\
\text { Disinfection was completed between } \\
1.5 \text { and } 3.5 \mathrm{~min}\end{array}$ \\
\hline [64] & $\begin{array}{l}\text { Surface water } \\
\text { (Wenyu River) }\end{array}$ & $\begin{array}{c}\mathrm{BOD}_{5}(\mathrm{mg} / \mathrm{L}): 19-26 ; \mathrm{COD}(\mathrm{mg} / \mathrm{L}): \\
53-69 ; \mathrm{NH}_{4}^{+}(\mathrm{mg} / \mathrm{L}): 17-27 \\
\mathrm{NT}(\mathrm{mg} / \mathrm{L}): 30-39 ; \text { chloride: } \\
95-102 \mathrm{mg} / \mathrm{L} ; \text { conductivity: } \\
680-720 \mu \mathrm{S} / \mathrm{cm}\end{array}$ & $\begin{array}{l}\mathrm{C}: \mathrm{W}: \mathrm{L}=10 \mathrm{~m} \times 2 \mathrm{~m} \times 0.5 \mathrm{~m} ; \\
\text { Plant: Canna indica; media: Lava }\end{array}$ & $\begin{array}{c}\text { Anodes: } \mathrm{Ti} / \mathrm{TiO}_{2} / \mathrm{RuO}_{2} / \mathrm{IrO}_{2} \text {; cathode: } \\
\text { stainless steel; electrolytic cell: } \\
\mathrm{L} \times \mathrm{B} \times \mathrm{H}=0.6 \mathrm{~m} \times 0.6 \mathrm{~m} \times 1.5 \mathrm{~m} \text {; } \\
25 \text { electrodes of } 60 \mathrm{~cm} \\
\text { (length) } \times 60 \mathrm{~cm}(\text { width }) \times 1 \mathrm{~mm} \\
\text { (thickness); electrode gap: } 1 \mathrm{~cm} \text {; } \\
\text { current applied: } 350,660 \text { and } 750 \mathrm{~A}\end{array}$ & $\begin{array}{c}\text { Energy consumption } 38.4 \mathrm{kWh} / \mathrm{kg} \text {. } \\
\text { Treated effluent meet surface water } \\
\text { quality standards }\end{array}$ \\
\hline [65] & $\begin{array}{l}\text { Olive pomace } \\
\text { leachate }\end{array}$ & $\begin{array}{l}\text { COD }(\mathrm{mg} / \mathrm{L}): 9740 ; \text { solids }(\mathrm{mg} / \mathrm{L}): \\
\text { 1900; color }=16450 \text { True Colour Units } \\
\text { (TCU); conductivity }(\mu \mathrm{S} / \mathrm{cm}): \\
\text { 14300; pH: 8.2; TN }(\mathrm{mg} / \mathrm{L}): 35.2 \\
\text { TP }(\mathrm{mg} / \mathrm{L}): 19 ; \mathrm{EC}_{50}: 3.8\end{array}$ & $\begin{array}{l}\text { Organic loading rate: } \\
\text { 10-15 g COD } / \mathrm{m}^{2} \mathrm{~d} ; \text { Fed: intermittent; } \\
\text { Hydraulic loading rate: } \\
\leq 0.008 \mathrm{~m}^{3} / \mathrm{m}^{2} \mathrm{~d}\end{array}$ & $\begin{array}{l}\text { Anode: BDD; cathode: stainless steel; } \\
\text { electrolytic cell: area electrodes: } 70 \mathrm{~cm}^{2} \text {; } \\
\text {; electrode gap: } 1 \mathrm{~cm} \text {; volume: } 10 \mathrm{~L} \text {; cur- } \\
\text { rent applied: } 20 \mathrm{~A} \text {; electrolysis time: } 360 \\
\text { min; mix: } 5.5-10 \mathrm{~L} / \text { min with peristaltic } \\
\text { pump; electrolyte support: none }\end{array}$ & $\begin{array}{c}\text { Energy consumption } 1 \mathrm{kWh} / \mathrm{kg} \text { COD } \\
\text { COD removal: } 24,38 \text { and } 41 \% \text { for } \\
14100,9740 \text { and } 6250 \mathrm{mg} / \mathrm{L} \\
\text { respectively }\end{array}$ \\
\hline [36] & $\begin{array}{l}\text { Phenanthrene } \\
\text { (PHE) and } \\
\text { Tween } 80\end{array}$ & $\begin{array}{l}1.31 \mathrm{~g} \mathrm{TW} 80 / \mathrm{L} ; 25 \mathrm{mg} \mathrm{PHE} / \mathrm{L} ; \\
\operatorname{COD}(\mathrm{mg} / \mathrm{L})=2,700\end{array}$ & $\begin{array}{l}\text { Working volume: } 1 \mathrm{~L} \text {; } \\
\text { before experiments, } \\
\text { microbial cultures } \\
\text { were acclimated for } 2 \text { weeks }\end{array}$ & $\begin{array}{l}\text { Anode: } \mathrm{BDD} \text {; cathode: stainless steel; } \\
\text { area electrodes: } 28 \mathrm{~cm}^{2} \text {; electrode gap: } \\
3 \mathrm{~cm} \text {; volume: } 330 \mathrm{~mL} \text {; current applied: } \\
2 \mathrm{~A}\left(50 \mathrm{~mA} / \mathrm{cm}^{2}\right) ; \text { support electrolyte: } \\
0.05 \mathrm{M} \mathrm{Na}_{2} \mathrm{SO}_{4}\end{array}$ & $\begin{array}{l}\text { EO as post-treatment reached high } \\
\text { quality effluent. Biodegradability } \\
\text { increased from }<0.03 \text { to } 0.44\end{array}$ \\
\hline [58] & $\begin{array}{c}\text { wastewater } \\
\text { containing } \\
\text { aromatic } \\
\text { sulphonated acids }\end{array}$ & $\begin{array}{l}\mathrm{COD}(\mathrm{mg} / \mathrm{L}): 700-1300 \mathrm{mg} / \mathrm{L} ; \mathrm{N}^{-N}{ }_{4}^{+} \\
\quad(\mathrm{mg} / \mathrm{L}):<10 ; \mathrm{P}^{-} \mathrm{PO}_{4}(\mathrm{mg} / \mathrm{L}): 0.4 \\
\text { benzene and naphthalene sulfonates: } 30- \\
\text { ls } 60 \% \text { of COD; conductivity: } \sim 2 \mathrm{mS} / \mathrm{cm}\end{array}$ & $\begin{array}{l}\text { Biofilm airlift suspension reactor; } \\
\text { V: } 9.5 \mathrm{~L} ; \mathrm{pH}: 7 \text {; high: } 1640 \mathrm{~mm} \text {; } \\
\text { biomass: } 300 \mathrm{mg} / \mathrm{L}\end{array}$ & $\begin{array}{l}\text { Anode: BDD; area electrodes: } 25 \mathrm{~cm}^{2} \text {; } \\
\text { electrode gap: } 0.5 \mathrm{~cm} \text {; volume: } \\
115 \mathrm{~mL} \text {; current applied: } 0.5 \mathrm{~A} \text {; } \\
\text { electrolysis time: } 180-240 \mathrm{~min}\end{array}$ & $\begin{array}{c}\text { The EO as the only oxidation process } \\
\text { had a consumption of } 80 \mathrm{kWh} / \mathrm{m}^{3} \text { and } \\
4 \mathrm{~h} \text {. The energy consumption } \\
\text { decreased when coupling a BOP as } \\
\text { pretreatment to } 61 \mathrm{kWh} / \mathrm{m}^{3} \text { and } 3 \mathrm{~h}\end{array}$ \\
\hline
\end{tabular}


Table 3. Continued

\begin{tabular}{|c|c|c|c|c|c|}
\hline Ref. & $\begin{array}{c}\text { Wastewater } \\
\text { origin }\end{array}$ & $\begin{array}{l}\text { Characterization of } \\
\text { wastewater }\end{array}$ & $\begin{array}{l}\text { Biological treatment and } \\
\text { operation conditions }\end{array}$ & $\begin{array}{l}\text { Electro-oxidation process } \\
\text { operation conditions }\end{array}$ & Main results \\
\hline [66] & $\begin{array}{c}\text { Basic yellow } \\
28 \text { dye } \\
\text { (BY28) }\end{array}$ & $\begin{array}{c}\mathrm{COD}(\mathrm{mg} / \mathrm{L}): 125 ; \mathrm{BOD}_{5}(\mathrm{mg} / \mathrm{L}): 9.5 \\
\mathrm{BOD}_{5} / \mathrm{COD}: 0.076\end{array}$ & $\begin{array}{l}\text { Activated sludge; batch; } \\
\text { hydraulic retention time: } 30 \mathrm{~d} \text {; } \\
\text { MLSSV: } 0.5 \mathrm{~g} / \mathrm{L} ; \mathrm{pH}: 7 ; \\
\text { temperature: } 25^{\circ} \mathrm{C} ; \text { mix: } 300 \mathrm{rpm}\end{array}$ & $\begin{array}{c}\text { Anode: } \mathrm{Pb} / \mathrm{PbO}_{2} ; \text { cathode: } \mathrm{Pt} \text {; } \\
\text { volume: } 500 \mathrm{~mL} ; \\
\text { current applied: } 2.5-25 \mathrm{~mA} / \mathrm{cm}^{2} \text {; } \\
\text { temperature: } 20-60^{\circ} \mathrm{C} ; \\
\text { initial concentration: } 12-134 \mathrm{mg} / \mathrm{L} \text {; } \\
\text { mix: } 240-720 \mathrm{rpm}\end{array}$ & $\begin{array}{c}\mathrm{BOD}_{5} / \mathrm{COD}: 0.3 \text {; temperature } \\
\text { and initial concentration most } \\
\text { important factors; optimal conditions: } \\
\text { temperature: } 50-60^{\circ} \mathrm{C} \text {, current density: } \\
8.125-25 \mathrm{~mA} / \mathrm{cm}^{2}, \mathrm{BY} 28: 134 \mathrm{mg} / \mathrm{L} \text {, } \\
\text { and mix of } 720 \mathrm{rpm} \text {; } \\
\text { combined process EO/BOPs reached } \\
93 \% \text { removal in COD }\end{array}$ \\
\hline [36] & $\begin{array}{l}\text { Polycyclic } \\
\text { aromatic } \\
\text { hydrocarbons } \\
\text { removal } \\
\text { (phenanthrene } \\
\text { and } \\
\text { Tween }^{\circledR} 80 \text { ) }\end{array}$ & $\begin{array}{l}\text { Initial concentration of TW80: } 1.31 \mathrm{~g} / \mathrm{L} \\
\text { and } 25 \mathrm{mg} \text { Phenanthrene/L; } \\
\mathrm{COD}(\mathrm{g} / \mathrm{L}): 2.7 \text {; mineral nutrients: } \\
\mathrm{CaCl}_{2}(27.5 \mathrm{mg} / \mathrm{L}) \\
\mathrm{FeCl}_{3} 6 \mathrm{H}_{2} \mathrm{O}(0.25 \mathrm{mg} / \mathrm{L}) \\
\mathrm{MgSO}_{4} 7 \mathrm{H}_{2} \mathrm{O}(0.34 \mathrm{mg} / \mathrm{L}) \\
\mathrm{CoCl}_{2} 6 \mathrm{H}_{2} \mathrm{O}(0.084 \mathrm{mg} / \mathrm{L})\end{array}$ & $\begin{array}{c}\text { Aerobic biological reactor } \\
\text { with activated sludge. } \\
\text { Operation: }>2.5 \mathrm{mg} \mathrm{O} / \mathrm{L} \mathrm{pH} 6.5-7.5 \\
300 \mathrm{rpm} ; \mathrm{COD}: \mathrm{N}: \mathrm{P}>100: 5: 1 \\
0.35 \pm 0.05 \mathrm{~g} \mathrm{VSS} / \mathrm{L}\end{array}$ & $\begin{array}{c}\text { Anode: } \mathrm{Nb} / \mathrm{BDD} \text {; cathode: stainless } \\
\text { steel; volume: } 330 \text { and } 800 \mathrm{~mL} \text {; } \\
\text { current applied: } 200-1000 \mathrm{~mA} \\
\text { electrode gap: } 3 \mathrm{~cm} ; \\
\text { electrolyte: } \mathrm{Na}_{2} \mathrm{SO}_{4} 0.05 \mathrm{M} \\
\text { electrolysis time: } 0-5 \mathrm{~h}\end{array}$ & $\begin{array}{l}\text { EO alone required } 5 \mathrm{~h} \text { and } 1 \mathrm{~A} \text { to } \\
\text { remove } 95 \% \text { pf phenanthrene and } \\
\text { Tween }{ }^{\circledR} 80 \text { and } 71 \% \text { of COD; } \\
\text { biological treatment alone allowed a } \\
\text { total degradation of both pollutants but } \\
44 \% \text { COD. In combination EO as post } \\
\text { treatment let to } 93 \% \text { COD removal at } \\
500 \mathrm{~mA} \text { for } 5 \mathrm{~h} \text {. }\end{array}$ \\
\hline [12] & $\begin{array}{l}\text { 4,4-diaminos- } \\
\text { tilbene-2,2- } \\
\text { disulfonic acid }\end{array}$ & $\begin{array}{c}\mathrm{COD}(\mathrm{mg} / \mathrm{L}): 532 ; \text { TOC }(\mathrm{mg} / \mathrm{L}): 138 \\
\mathrm{BOD}_{5}(\mathrm{mg} / \mathrm{L}): 80 ; \mathrm{pH}: 7.76 ; \text { sulfate } \\
(\mathrm{mg} / \mathrm{L}): 1940 ; \text { chloride }(\mathrm{mg} / \mathrm{L}): 3000 ; \\
\text { salinity }(\mathrm{mg} / \mathrm{L}): 6146 ; \text { conductivity } \\
(\mathrm{mS} / \mathrm{cm}): 5.53 ; \text { note: } \\
\text { characterization of biologically } \\
\text { pretreated dye wastewater }\end{array}$ & $\begin{array}{l}\text { zero-valent iron } \\
\text { and coagulation and UASB }\end{array}$ & $\begin{array}{l}\text { Anode: Nb/BDD; cathode: stainless } \\
\text { steel; volume: } 37.2 \mathrm{~mL} ; \\
\text { current applied: } 20 \mathrm{~mA} / \mathrm{cm}^{2} \\
\text { electrolysis time: } 180-240 \mathrm{~min} \\
\text { electrode gap: } 1.55 \mathrm{~cm}\end{array}$ & $\begin{array}{l}\text { COD was decreased from } \\
532 \text { to } 99 \mathrm{mg} / \mathrm{L} ; \text { biologically } \\
\text { pretreated effluent presented } 27 \% \\
\text { inhibition ratio of luminescence, } \\
\text { which increased to } 68 \% \text { after } 2 \mathrm{~h} \text { of } \\
\text { EO. Only after } 6 \mathrm{~h} \text {, the toxicity of } \\
\text { wastewater was almost negligible. }\end{array}$ \\
\hline
\end{tabular}




\section{Electrooxidation process (EO) followed by an Biological Oxidation Process (BOP)}
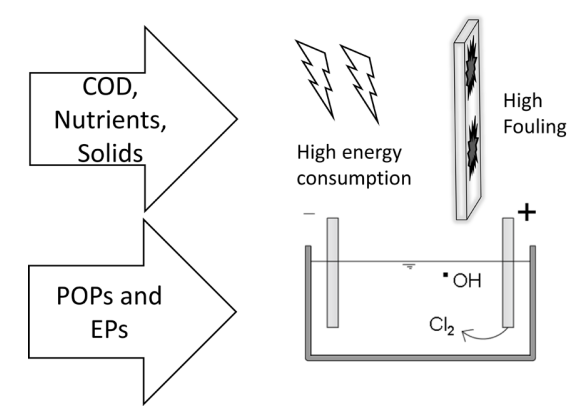

COD, Nutrients, Solids

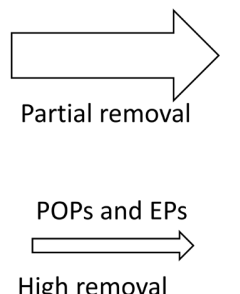

High removal

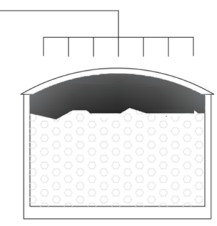

COD, Nutrients, Solids

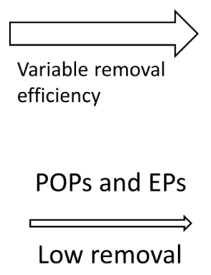

Fig. 4. Electrooxidation process (EO) followed by an Biological Oxidation Process (BOP)

As mentioned before, indirect oxidation involves the generation of by-products from chlorine (equation 3-6) whose presence in EO is one of the most significant factors (along with electrolysis time and current) in the removal of pollutants; the higher the concentration of $\mathrm{Cl}^{-}$ions, the greater the efficiency in the removal of organic matter and POPs/EPs. Of course there is an optimum that can be found as a ratio $\mathrm{COD} /\left[\mathrm{Cl}^{-}\right]$in which the removal of organic compounds will no longer increase $[37,67]$.

$$
\begin{aligned}
& \mathrm{Cl}^{-}+\bullet \mathrm{OH} \rightarrow \mathrm{ClO}^{-}+\mathrm{H}^{+}+e^{-} \\
& \mathrm{ClO}^{-}+\bullet \mathrm{OH} \rightarrow \mathrm{ClO}_{2}^{-}+\mathrm{H}^{+}+e^{-} \\
& \mathrm{ClO}_{2}^{-}+\bullet \mathrm{OH} \rightarrow \mathrm{ClO}_{3}^{-}+\mathrm{H}^{+}+e^{-} \\
& \mathrm{ClO}_{3}^{-}+\bullet \mathrm{OH} \rightarrow \mathrm{ClO}_{4}^{-}+\mathrm{H}^{+}+e^{-}
\end{aligned}
$$

The presence of $\mathrm{Cl}^{-}$improves the removal of organic compounds and has been evaluated by many authors. Tavares et al. [67] used $\mathrm{NaCl}(0.2 \mathrm{~mol} / \mathrm{L})$ as supporting electrolyte to degrade basic blue 99 dye in 5 min with DSA ${ }^{\circledR}$ electrodes, unlike the $60 \mathrm{~min}$ it took using $\mathrm{Na}_{2} \mathrm{SO}_{4}(0.2 \mathrm{~mol} / \mathrm{L})$ as supporting electrolyte. Similarly, Serrano-Torres et al. [68] degraded Diazo dye Congo ( $99 \%$ removal) faster (5 min) using $\mathrm{NaCl}(0.05 \mathrm{~mol} / \mathrm{L})$ compared to $\mathrm{HClO}_{4}, \mathrm{Na}_{2} \mathrm{SO}_{4}$ and $\mathrm{H}_{2} \mathrm{SO}_{4}$. Differences were significant with $\mathrm{Na}_{2} \mathrm{SO}_{4}$ which removed $97 \%$ in $180 \mathrm{~min}$. In EPs like pharmaceuticals, Giraldo et al. [60] studied the total transformation of oxacillin to biodegradable compounds in 4 min using $225 \mathrm{mM}$ of $\mathrm{NaCl}$ at $30.25 \mathrm{~mA} / \mathrm{cm}^{2}$ and $\mathrm{Ti} /$
$\mathrm{IrO}_{2}$ as an anode. This shows how the electrolytic support is a determining factor in the removal of recalcitrant pollutants in conjunction with the current density and the electrolysis time.

However, the main drawback of using $\mathrm{NaCl}$ as a supporting electrolyte is the formation of disinfection by-products (DBPs) as a result of the oxidation of organic compounds present in the water. Among these DBPs, THMs are a majority group that include chloroform $\left(\mathrm{CHCl}_{3}\right)$, bromodichloromethane $\left(\mathrm{CHCl}_{2} \mathrm{Br}\right)$ and bromoform $\left(\mathrm{CHBr}_{3}\right)$, all possibly carcinogenic to humans $[44,69]$. On the other hand, with short retention times as those mentioned above, it is very likely that the formation of chlorinated and quinones species continues in the effluent, even at low concentrations. These substances are toxic and biorecalcitrant [49]. In addition, it is necessary to take into account the by-products of the pollutant. For example, Torres et al. [49] completely degraded 5-amino-6methyl-2-benzimidazolone in 45 min of electrolysis time (Anode: Pt and $50 \mathrm{~mA} / \mathrm{cm}^{2}$ ). However, it resulted in a toxicity increase. After only $4 \mathrm{~h}$ of electrolysis, the effluent was considered suitable for biological degradation, which was achieved with a fixed bed reactor. In this regard, Grafias et al. [65] evaluated the treatment of the olive oil extraction agroindustry; using EO with a BDD anode for $360 \mathrm{~min}$ and $20 \mathrm{~A}$ of current as the first stage of the treatment and then a constructed wetland $(\mathrm{CW})$ as post-treatment $(\mathrm{EO} / \mathrm{CW})$. These authors found that the microbial consortium in the $\mathrm{CW}$ was negatively affected by the rise of toxicity of the EO effluent, which decreased the removal of COD and color. García-espi- 


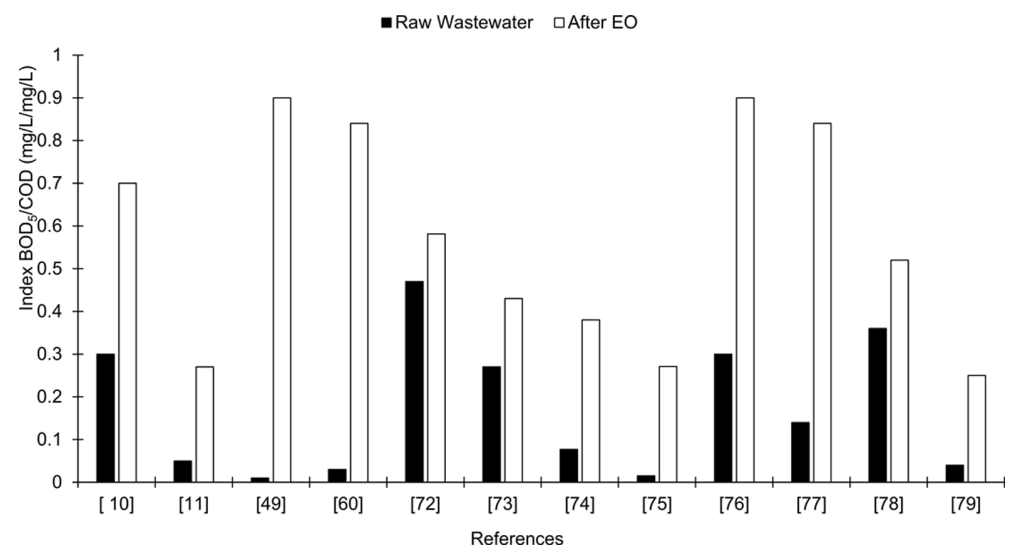

Fig. 5. Biodegradability index (BOD5/COD) for different industrial effluents, before and after an EOP reported in literature. [10] Electronic industry, [11] Coking Wastewater, [49] 5-amino-6methyl-2benzimidazolone, [60] antibiotic oxacillin, [72] Drug I

noza et al. [69] degraded carbamazepine with a BDD electrode and with $14 \mathrm{mM}$ of $\mathrm{NaCl}$ as a supporting electrolyte. However, the accumulation of chlorine was reported at longer electrolysis times, which resulted in a greater toxicity for Vibrio fischeri.

There are guidelines for drinking water regarding the discharge of these DBPs. The maximum permitted concentrations for total THMs established by are the USEPA and the European Union $80 \mu \mathrm{g} / \mathrm{L}$ and $100 \mu \mathrm{g} / \mathrm{L}$, respectively [70]. These limits could be easily exceeded, for example, Pérez et al. [70] treated the rejection of a reverse osmosis process (with $800 \mathrm{mg} / \mathrm{L}$ of chloride) and found that by applying $20 \mathrm{~mA} / \mathrm{cm}^{2}$ almost $200 \mu \mathrm{g} / \mathrm{L}$ of THMs were present in the treated effluent (exceeding the guidelines). Feng et al. [44] used $110 \mathrm{mg} / \mathrm{L}$ of chloride and 4.2 $\mathrm{mA} / \mathrm{cm}^{2}$ during $20 \mathrm{~min}$ for the disinfection of rainwater and generated $34 \mu \mathrm{g} / \mathrm{L}$ of THMs, concentration below the guideline limits but using a relatively low current density and short time.

\subsubsection{Enhancing biodegradability}

The desirable effect of EO as pre-treatment is to enhance the biodegradability of the industrial effluent to be treated. The aim of the pre-treatment is to partially oxidize the persistent part of the effluent and to produce biodegradable intermediates [15]. The percentage of mineralization, however, must be minimal in order to allow the subsequent BOPs to degrade these intermediaries and thus avoid unnecessary expenditure on chemicals and energy [71].
Examples of works where the biodegradability of the effluent is improved after an EO process, increasing the $\mathrm{BOD}_{5} / \mathrm{COD}$ ratio are presented in Fig. 5 .

$\mathrm{A} \mathrm{BOD}_{5} / \mathrm{COD}$ ratio of 0.4 is considered as the limit of biodegradability to submit an effluent to biological treatment [66]. Therefore, for values below, it is highly advisable to pretreat with EO, as is the case of many industrial effluents such as irrigation wells contaminated with herbicides (2,4-Dichlorophenoxyacetic acid) paper, dyes, pharmaceutical effluents, leachates, among others.

3.1.3 Interferences by solids

One of the limitations of the EO is that the persistent pollutants of interest must be adsorbed first at the anode in order to be directly oxidized [66]. If the EO is used as a pre-treatment, the solids present in the raw wastewater make it difficult to transfer the recalcitrant pollutants to the anode, reducing the efficiency of the process. Additionally, many POPs and EPs can become adsorbed on solids, which reduces the possibility of them getting in contact with electrogenerated $\bullet \mathrm{OH}$. Barrios et al. [8] evaluated the performance of an EO process with BDD electrodes to treat sludge with a concentration of $0.8 \%$ and concluded that the low degradation of non-phenols and triclosan was due to the fact that $>98 \%$ of these compounds remained associated (adsorbed) to solids. Efi Kotta [80] found a decrease in the efficiency of the treatment of organic matter due to the presence of high concentrations of solids $(80 \mathrm{~g} / \mathrm{L})$ in the industrial effluent of olive bleached pulp, in addition to the 
rise of soluble COD due to the oxidation of solids at the anode. García-espinoza et al. [69] found a reduction in the first-order kinetic constant in the degradation of carbamazepine by using demineralized water, tap water and treated residual water of $0.189,0.071$ and $0.0351 / \mathrm{min}$, respectively, which could be explained by a possible competition of solids and carbamazepine for the hydroxyl radicals or, by the fouling of the electrodes that affect the efficiency of the process.

\subsection{EO as post-treatment: Advantages and disad- vantages}

Unlike EO as a pre-treatment, EO as a post-treatment is a less frequent arrangement but there are studies that have been carried out for all types of effluents: industrial, municipal, domestic and even of natural water currents (rivers) (Fig. 6). There are also few reports that compare both treatment configurations, that is, EO as pre and post-treatment and thus evaluate the differences in different types of effluents.

EO as post-treatment takes place in the following cases: (1) after the biodegradable organic pollutants have been previously degraded in BOPs in order to oxidize the remaining organic matter (which is usually more bio-resistant), (2) to remove trace contaminants such as pharmaceuticals and pesticides and (3) to remove color in case of reuse in an industrial process such as paper and textiles. In this way, all kinds of effluents have been studied, such as: traces after an anaerobic treatment Vidal et al. [81]; reverse osmosis rejection treatment that treated water from a secondary effluent [82-84]; leached from olive pulp previously treated in a CW [65] and through an upflow anaerobic sludge blanket (UASB) [43]; leachate from sanitary landfills pretreated with activated sludge $[39,61]$, or pretreated by a membrane bioreactor
(MBR) [62] and by ultrafiltration [63]; the treatment of paper pulp pretreated with an UASB [85]; tannery (it does not specify biological process) [86]; door manufacturing processes with activated sludge [87] and even hospitals previously using a MBR [13].

During the EO as a post-treatment, a decrease in the risk unwanted by-products formation such as THMs can be expected. Frontistis et al. [40] for example, found a decline in aromatics content after 30 min of EO, however, risk was not evaluated.

In hospital effluents, EPs like pharmaceuticals are of great interest. These effluents are characterized by concentrations of pharmaceuticals from 4 and up to 150 times higher, compared to domestic and urban [88]. In this sense, Ouarda et al. [13], found that when using a MBR, the removal for carbamazepine and venlafaxine is very limited $(<10 \%)$, but by submitting the biologically pretreated effluent to EO, it was possible to remove these drugs in $40 \mathrm{~min}$ and with $0.5 \mathrm{~A}(\mathrm{Nb} / \mathrm{BDD})$. On the other hand, when the EO was used as pre-treatment, the removal of carbamazepine and venlafaxine was only 50 and $66 \%$, respectively. After applying a MBR process as a polish, the venlafaxine removal rose up to $92 \%$. This leads to concluding that the EO as a pre-treatment followed by a MBR is not the best option for hospital effluents. However, the configuration of EO as a post-treatment generates a toxic effluent to Daphnia magna and Vibrio fisheri if it is not diluted $(100 \% \mathrm{v} / \mathrm{v}$ toxicity). It was concluded that the EO as a post-treatment not only improves the removal efficiency of the evaluated pharmaceuticals but also decreases the energy consumption when going from a current intensity of 2 to $0.5 \mathrm{~A}$.

In this sense, Panizza et al. [58] found that treating an industrial effluent containing naphthalene sulfon-
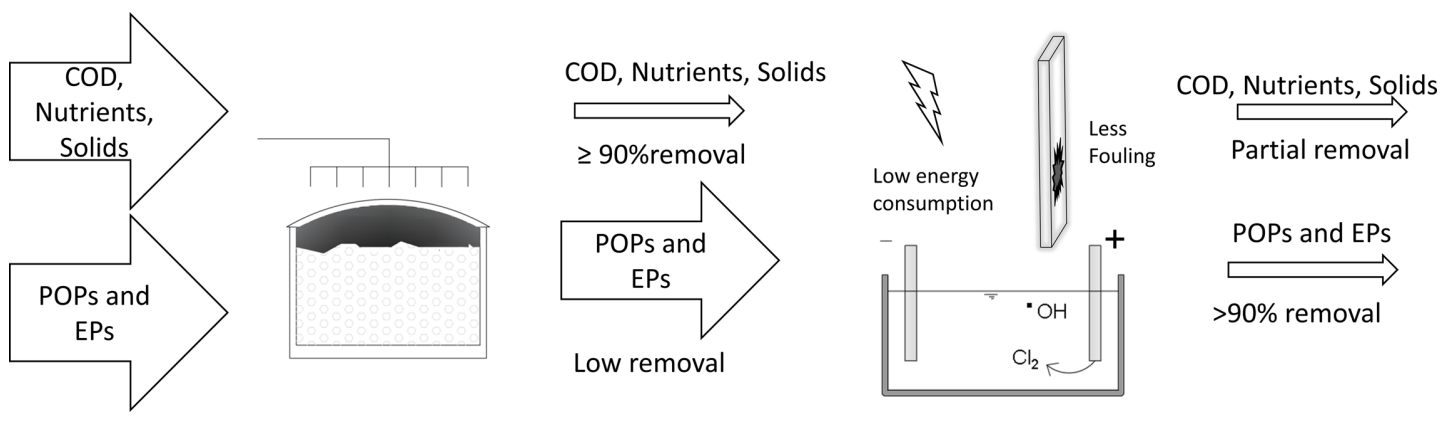

Fig. 6. Biological Oxidation Process (BOP) followed by an Electrooxidation process (EO). 
ates led to achieving mineralization when using EO as the only treatment, consuming $80 \mathrm{kWh} / \mathrm{m}^{3}$ in $4 \mathrm{~h}$. However, by applying a hybrid system biofilter/EO, the energy consumption decreased to $61 \mathrm{kWh} / \mathrm{m}^{3}$ in 3 $\mathrm{h}$. This means that the fouling of the electrodes caused by the increase in the organic load (when EO was used as pre-treatment) forced the electrolytic cell to be operated at a higher current than stoichiometrically required.

Iniesta et al. [57] found that at a low current density, high phenol concentration and low conversion, phenol is oxidized to aromatic compounds (benzoquinone, hydroquinone and catechol) which, according to Liu et al. [56], these type of compounds could further combine with phenol radicals to generate phenoxy phenol or dihydroxyl benzene which then transformed into a coating layer that covers the anode's surface. Since biological treatment removed phenol from water, fouling risk decreased at low current densities.

\section{EO in pilot scale applications}

The background of the EO in terms of wastewater treatment is sufficient to demonstrate the viability of the technology to remove POPs, EPs, organic matter, nutrients and pathogens from all types of waste effluents. Therefore, the logical step to follow is to apply this technology on a larger scale (pilot or full-scale). This section will examine the progress in scaling up EO processes. The methodology details and the problems encountered during the implementation process (for large scale application) will also be presented.

In order to scale conventional biological processes (activated sludge, trickling filters, wetlands, etc.) from results at the laboratory level, it is very important to preserve the dimensional relationships of the corresponding reactor. However, in the case of electrochemical reactors, this criterion usually cannot be met, since the increase in the interelectrode space would result in a high voltage drop and, therefore, an increase in energy costs. Thus it is always better to reduce this distance as much as possible within a certain limit $[89,90]$.

The safest route for the scaling of electrochemical reactors is through the use of multiple laboratoryscale electrochemical cells [91]. According to Anglada et al. [39] and Urtiaga et al. [51] the degradation constant of the pollutant will be similar regardless of the number of cells that are operated simultaneously, while the hydrodynamic conditions are maintained. Thus, the model proposed by Comninellis and Chen. [38] represented in equations 7 and 8 can be applied.

$$
\begin{aligned}
& j_{\text {lim }}=4 F k_{m} C O D_{(t)} \\
& C O D_{(t)}=C O D_{0} \exp \left[-\frac{A}{V} k_{m} t\right]
\end{aligned}
$$

Where $j_{\text {lim }}$ is the limiting current density $\left(\mathrm{A} / \mathrm{m}^{2}\right), A$ $\left(\mathrm{m}^{2}\right)$ is the area of the anode, $\mathrm{V}\left(\mathrm{m}^{3}\right)$ is the volume of treated wastewater, $\mathrm{k}_{\mathrm{m}}$ is the mass transport coefficient in the electrochemical reactor $(\mathrm{m} / \mathrm{s}), \mathrm{COD}$ is the chemical oxygen demand at a given time and $\mathrm{F}$ is the Faraday constant $(\mathrm{C} / \mathrm{mol})$.

From a series of degradation tests and calculating the mass transport coefficient $\left(\mathrm{k}_{\mathrm{m}}\right)$, Anglada et al. [39] scaled up a process from laboratory test up 150 times, that is, with a total BDD anode area of $1.05 \mathrm{~m}^{2}$ and using several individual cells (area per cell $70 \mathrm{~cm}^{2}$ ), the results obtained for a single cell satisfactorily described what happened at the pilot level, for the removal of both organic matter and ammonia nitrogen. Since the EO is a non-selective process, the kinetic models apply to any type of molecule that adds COD to the system [92]. In this sense Urtiaga et al. [51] carried out a series of degradation kinetics at laboratory scale using different operating conditions (initial COD 1500 - $3000 \mathrm{mg} / \mathrm{L}$, current density 300, 600 and $1200 \mathrm{~A} / \mathrm{m}^{2}$ ) in order to scale up; COD degradation levels reached in the pilot scale validated the procedure in which the $\mathrm{A} / \mathrm{V}$ ratio was preserved.

There is a shared opinion among some authors that the safest route for scaling is multiplying the number of cells tested at laboratory scale. This is challenged by others who say that it is likely that the scaling can be performed only by maintaining hydrodynamics of the cell studied at the laboratory level and maintaining the $\mathrm{A} / \mathrm{V}$ ratio. For instance, $\mathrm{Zhu}$ et al. [48] scaled a $24 \mathrm{~cm}^{2}$ BDD anode 121 times $\left(2904 \mathrm{~cm}^{2}\right)$ for the removal of phenols. The dimensional relations were maintained in the configuration of the electrode and in the working volume. However, the interelectrode distance and the operating variables (current densities, retention times, conductivity and initial COD) were the same in both scales. It should be noted that the analysis of the kinetic behavior was not performed and only the hydrodynamics and the $\mathrm{A} / \mathrm{V}$ ratio were maintained. After the scaling up, the 
results were very similar to those obtained at laboratory scale according to the response surface methodology in which a relatively small standard deviation of 0.2 to $12 \%$ was found.

Another way to approach scaling is the one presented by Abou et al. [93], who used a single cell with an effective volume of $19.2 \mathrm{~L}$ that contains 49 graphite electrodes with a total area of $0.0126 \mathrm{~m}^{2}$, maintaining a distance of $2 \mathrm{~cm}$ for each pair of electrodes (Fig. 7). In this way, a large number of electrodes can be installed until the desired $\mathrm{A} / \mathrm{V}$ ratio is reached. This pilot prototype was evaluated to remove phenols from wastewater from the oil industry, obtaining $>99 \%$ efficiency in phenols and 40 to $60 \%$ removal of COD.

More recently, Monteil et al. [94] developed a novel pilot-scale reactor to operate in continuous mode. This reactor consists on a cell with a useful volume of $22.5 \mathrm{~L}$ in the form of a channel that works with 14 and 28 pairs of electrodes (BDD) (Fig 8). The authors evaluated the effect of the flow (20.4 to $170 \mathrm{~mL} / \mathrm{min}$ ) on the mineralization of the drug hydrochlorothiazide in the solution. The results showed that the flow rate was the most critical parameter: the lower the flow rate, the higher the mineralization percentage. The number of electrodes in both configurations allowed a high mineralization efficiency $(>90 \%)$.

The scaling of EO, although successful, it is currently limited to a pilot scale; the main constraint being that, in order to treat a relatively large effluent, several hundreds of small electrolytic cells are required. The technological development should be focused on the creation of large electrodes (such as those used by Zhu et al. [48]) that result in the use of a small number of electrolytic cells to treat high volumes or be focused on the creation of large electrolytic cells with many electrodes (such as those used by $[93,94])$. On the other hand, BDD electrodes are considered to deliver the best performance in wastewater treatment. However, it is very expensive when compared to DSA ${ }^{\circledR}$, carbon or graphite electrodes $[92,95]$. Therefore, a larger research is needed using these electrodes at a pilot scale.

\section{EO coupling to BOPs challenges and future developments}

- Taking into account that DBPs are dangerous

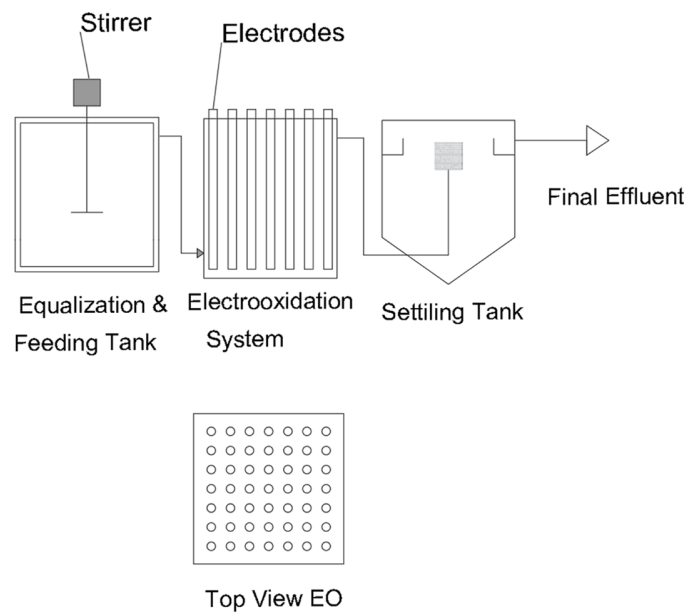

Fig. 7. Pilot prototype electrooxidation system to treat wastewater from the oil industry. Modified from Abou et al. [93]

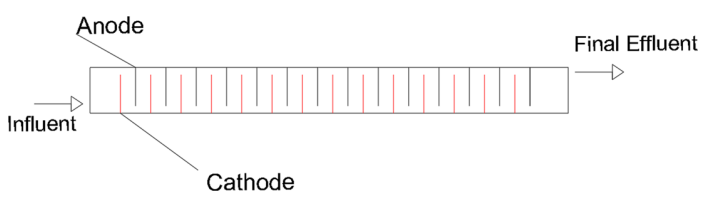

Fig. 8. Pilot-scale reactor operate in continuous mode. Modified from Monteil et al. [94].

substances, all studies related to EO should closely monitor their formation. It takes place while there are low concentrations of $\mathrm{Cl}^{-}$such as $119-144 \mathrm{mg} / \mathrm{L}$, or as high as $4500 \mathrm{mg} / \mathrm{L}[37,45]$ and the applied current density is high enough to favor the evolution of $\mathrm{Cl}^{-}$to DBPs.

- There are still insufficient studies that rigorously monitor the formation of DBPs in the final discharge, as well as the optimal $\mathrm{COD} / \mathrm{Cl}^{-}$ratios to avoid an increase in the toxicity of effluents treated by EO. There is a limited number of proposals to solve this problem which, along with the high costs, is a great limitation for scaling up.

- There are scarce studies in passivation/fouling focused on long retention times and cleaning/reactivation methods. Efforts are needed in this direction to investigate the feasibility of this technology on a pilot / industrial scale.

- The future developments to scale up the EO process should be aimed at manufacturing cheaper and larger electrodes, in order to decrease the number of 
electrolytic cells used, thus increasing the treatment capacity to full scale.

\section{Conclusions}

EO has proven to be an efficient process to remove recalcitrant pollutants. In addition, its implementation is relatively easy and versatile to treat different effluents. However, in general, it is expensive due to two factors: 1) Long reaction times are required, sometimes hours if the mineralization of POPs and EPs is to be achieved, and 2) the manufacture of some electrodes is expensive.

On the other hand, the unavoidable generation of toxic disinfection and degradation by-products complicates the reuse and / or discharge of an EO-treated effluent. Therefore, various studies recommend that EO be used in combination with a biological process. EO as a pre-treatment is generally applied to increase the biodegradability of an industrial effluent. However, the operation is complicated because: 1) Sufficient substrate must be maintained in the effluent for the subsequent biological process and 2) Generally, there is little control regarding the generation of toxic by-products of disinfection and degradation, which affect the microorganisms of the subsequent biological system. In this sense, the most promising configuration of this coupling seems to be EO as a posttreatment, since solids, organic matter and nutrients are eliminated in the biological stage, thus concentrating the generation of $\mathrm{OH}$ radicals from $\mathrm{EO}$ to mineralize the more persistent pollutants. By applying $\mathrm{EO}$ as a post-treatment, the generation of disinfection by-products such as THMs could also decrease by limiting their precursors such as organic matter or nutrients. An additional benefit is to decrease the formation of a polymeric layer on the surface of the electrodes and therefore their fouling.

So far, the number of studies carried out with EO on an industrial / real scale is limited, although the results obtained on a laboratory scale on a pilot / industrial scale have been successfully replicated. This has been achieved by maintaining the hydrodynamics of the electro-oxidation cell (same A / V ratio) either by using many laboratory-scale cells connected in parallel or by developing larger electrooxidation cells with a pair of electrodes that are also larger or by placing many laboratory-scale electrodes distributed in larger electrolyte cells.

\section{Acknowledgements}

This study was sponsored by Instituto Politécnico Nacional (SIP 20171847; SIP 20170184; SIP 20180337), and by Consejo Nacional de Ciencia y Tecnología (CONACYT) by the scholarship granted to $\mathrm{PhD}$ student Javier A. Navarro Franco.

\section{List of Abbreviations}

AOPs $=$ Advanced oxidation processes

$\mathrm{A} / \mathrm{V}=$ Area/Working volume

$\mathrm{BDD}=$ Boron doped diamond

BOPs $=$ Biological Oxidation Processes

$\mathrm{EO}=$ Electro-oxidation

EPs $=$ Emerging pollutants

$\mathrm{MBR}=$ Membrane Bioreactor

- $\mathrm{OH}=$ Hydroxyl radicals

POPs $=$ Persistent Organic Pollutants

PAHs $=$ Polycyclic aromatic hydrocarbons

THMs=Trihalomethanes

$\mathrm{UASB}=$ Upflow anaerobic sludge blanket

$\mathrm{UV}=$ Ultraviolet visible

WWTPs $=$ Wastewater Treatment Plants

\section{References}

[1] M. J. Martín de Vidales, M. Millán, C. Sáez, J. F. Pérez, M. A. Rodrigo, and P. Cañizares, Chemosphere, 2015, 136, 281-288.

[2] S. Garcia-Segura, J. D. Ocon, and M. N. Chong, Process Saf. Environ. Prot., 2018, 113, 48-67.

[3] D. R. Baker and B. Kasprzyk-Hordern, Sci. Total Environ., 2013, 454, 442-456.

[4] O. Ganzenko, D. Huguenot, E. D. van Hullebusch, G. Esposito, and M. A. Oturan, Environ. Sci. Pollut. Res., 2014, 21(14), 8493-8524.

[5] O. M. Rodriguez-Narvaez, J. M. Peralta-Hernandez, A. Goonetilleke, and E. R. Bandala, Chem. Eng. J., 2017, 323, 361-380.

[6] P. Drogui, J. Blais, and G. Mercier, Recent Patents Eng., 2007, 1(3), 257-272.

[7] G. B. Tabrizi and M. Mehrvar, J. Environ. Sci. Heal. Part A, 2004, 39(11-12), 3029-3081.

[8] J. A. Barrios, A. Cano, J. E. Becerril, and B. Jiménez, J. Electroanal. Chem., 2016, 776, 148-151.

[9] L. Szpyrkowicz, S. N. Kaul, R. N. Neti, and S. Satyanarayan, Water Res., 2005, 39(8), 1601-1613.

[10] E. Mousset, Z. Wang, H. Olvera-Vargas, and O. Lefebvre, J. Hazard. Mater, 2018, 360, 552-559.

[11] C. R. Wang, Z. F. Hou, M. R. Zhang, J. Qi, and J. Wang, J. Chem., 2015, 2015.

[12] X. Zhu, J. Ni, J. Wei, X. Xing, and H. Li, J. Hazard. 
Mater, 2011, 189(1-2), 127-133.

[13] Y. Ouarda et al., Chemosphere, 2018, 193, 160-169.

[14] Á. Anglada, A. Urtiaga, and I. Ortiz, J. Chem. Technol. Biotechnol., 2009, 84(12), 1747-1755.

[15] I. Oller, S. Malato, and J. A. Sánchez-Pérez, Sci. Total Environ., 2011, 409(20), 4141-4166.

[16] M. Chettiar and A. P. Watkinson, Can. J. Chem. Eng., 1983, 61(4), 568-574.

[17] F. Pawlak, K. Kozioł, M. Ruman, and Ż. Polkowska, Monatshefte fur Chemie, 2019, 150(9), 1573-1578.

[18] J. N. Edokpayi, J. O. Odiyo, O. E. Popoola, and T. A. M. Msagati, Int. J. Environ. Res. Public Health, 2016, 13(4), 387.

[19] M. Biel-Maeso, C. Corada-Fernández, and P. A. LaraMartín, Water Res., 2019, 150, 129-139.

[20] B. Chen et al., Water Res., 2004, 38(16), 3558-3568.

[21] M. A. Alawi, I. N. Tarawneh, and Z. Ghanem, Toxin Rev., 2018, 37(2), 128-137.

[22] N. Z. Firouzsalari, M. Shakerkhatibi, M. Pourakbar, A. Yadeghari, G. H. Safari, and P. Sarbakhsh, J. Water Process Eng., 2019, 29, 100793.

[23] K. Ulucan-altuntas and E. Debik, 2020, 14(1), 1-13.

[24] A. Katsoyiannis and C. Samara, 2004, 38(11), 26852698.

[25] E. B. Estrada-Arriaga et al., Sci. Total Environ., 2016, 571, 1172-1182.

[26] M. Clara, B. Strenn, O. Gans, E. Martinez, N. Kreuzinger, and H. Kroiss, Water Res., 2005, 39(19), 4797-4807.

[27] C. Trautwein and K. Kümmerer, Chemosphere, 2011, 85(5), 765-773.

[28] O. O. Olayinka, A. A. Adewusi, O. O. Olujimi, and A. A. Aladesida, J. Health \& Pollution., 2018, 8(20), 1-12.

[29] V. Geissen et al., Int. Soil Water Conserv. Res., 2015, $3(1), 57-65$.

[30] World Health Organization (WHO), Health criteria and other supporting information-Addendum, Guidelines for Drinking-Water Quality, 1998.

[31] J. Margot, L. Rossi, D. A. Barry, and C. Holliger, Wiley Interdiscip. Rev. Water, 2015, 2(5), 457-487.

[32] D. Gao, H. Liang, L. Du, and J. Chen, African J. Biotechnol., 2010, 9(41), 6888-6893.

[33] A. de Wilt et al., J. Hazard. Mater, 2016, 304, 84-92.

[34] S. Wang and J. Wang, Environ. Technol., 2018, 39(15), 1985-1993.

[35] O. Rodríguez-Nava, H. Ramírez-Saad, O. Loera, and I. González, Environ. Technol., 2016, 37(23), 2964-2974.

[36] C. Trellu et al., Chem. Eng. J., 2016, 306, 588-596.

[37] A. Fernandes, D. Santos, M. J. Pacheco, L. Ciríaco, and A. Lopes, Sci. Total Environ., 2016, 541, 282-291.

[38] C. Comninellis and G. Chen, Electrochemistry for the Environment New York: Springer. 2010, 2015.

[39] Á. Anglada, A. M. Urtiaga, and I. Ortiz, J. Hazard. Mater, 2010, 181(1-3), 729-735.

[40] Z. Frontistis, C. Brebou, D. Venieri, D. Mantzavinos, and A. Katsaounis, J. Chem. Technol. Biotechnol., 2011,
86(10), 1233-1236.

[41] C. A. Martínez-Huitle et al., Chem. Soc. Rev., 2006, 35(12), 1324-1340.

[42] C. R. Wang, Z. F. Hou, M. R. Zhang, J. Qi, and J. Wang, 2015, 2015.

[43] A. Katsoni, D. Mantzavinos, and E. Diamadopoulos, Water Res., 2014, 57, 76-86.

[44] W. Feng, D. T. Mccarthy, R. Henry, X. Zhang, K. Zhang, and A. Deletic, Chemosphere, 2018, 213, 226234.

[45] V. Schmalz, T. Dittmar, D. Haaken, and E. Worch, Water Res., 2009, 43(20), 5260-5266.

[46] W. Feng, A. Deletic, Z. Wang, X. Zhang, T. Gengenbach, and D. T. McCarthy, Sci. Total Environ., 2019, 646, 1440-1447.

[47] I. Sirés, E. Brillas, M. A. Oturan, M. A. Rodrigo, and M. Panizza, Environ. Sci. Pollut. Res., 2014, 21(14), 8336-8367.

[48] X. Zhu, J. Ni, J. Wei, X. Xing, H. Li, and Y. Jiang, Journal of Hazardous Materials, 2010, 184(1-3). 493498.

[49] R. A. Torres, V. Sarria, W. Torres, P. Peringer, and C. Pulgarin, Water Res., 2003, 37(13), 3118-3124.

[50] J. Singla, A. Verma, and V. K. Sangal, J. Electrochem. Soc., 2017, 164(12), E312-E320.

[51] A. Urtiaga, P. Gómez, A. Arruti, and I. Ortiz, J. Chem. Technol. Biotechnol., 2014, 89(8), 1243-1250.

[52] L. H. Tran, P. Drogui, G. Mercier, and J. F. Blais, J. Hazard. Mater, 2009, 164(2-3), 1118-1129.

[53] C. García-Gómez et al., J. Electroanal. Chem., 2014, $732,1-10$.

[54] R. G. Simon et al., Chemie Ing. Tech., 2018, 90(11), 1832-1854.

[55] G. Crini and E. Lichtfouse, Environ. Chem. Lett., 2019, 17(1), 145-155.

[56] X. Liu, S. You, F. Ma, and H. Zhou, Front. Environ. Sci. Eng., 2021, 15(4), 1-10.

[57] J. Iniesta, P. A. Michaud, M. Panizza, G. Cerisola, A. Aldaz, and C. Comninellis, Russ. J. Electrochem., 2001, 46(23), 3573-3578.

[58] M. Panizza and G. Cerisola, Int. J. Environ. Pollut., 2006, 27(1-3), 64 .

[59] J. T. Jasper, Y. Yang, and M. R. Hoffmann, Environ. Sci. Technol., 2017, 51(12), 7111-7119.

[60] A. L. Giraldo, E. D. Erazo-Erazo, O. A. Flórez-Acosta, E. A. Serna-Galvis, and R. A. Torres-Palma, Chem. Eng. J., 2015, 279, 103-114.

[61] A. Fernandes, M. J. Pacheco, L. Ciríaco, and A. Lopes, J. Hazard. Mater, 2012, 199-200, 82-87.

[62] F. Feki, F. Aloui, M. Feki, and S. Sayadi, Chemosphere, 2009, 75(2), 256-260.

[63] Z. Ukundimana, P. I. Omwene, E. Gengec, O. T. Can, and M. Kobya, Electrochim. Acta, 2018, 286, 252-263.

[64] J. feng Peng, B. zhen Wang, Y. hui Song, P. Yuan, and Z. Liu, Ecol. Eng., 2007, 31(2), 92-97.

[65] P. Grafias, N. P. Xekoukoulotakis, D. Mantzavinos, and 
E. Diamadopoulos, Water Res., 2010, 44(9), 2773-2780.

[66] I. Yahiaoui, F. Aissani-Benissad, F. Fourcade, and A. Amrane, Environ. Prog. Sustain. Energy, 2013, 33(1), 160-169.

[67] M. G. Tavares, D. H. da S. Santos, S. J. A. Torres, W. R. O. Pimentel, J. Tonholo, and C. L. de P. e S. Zanta, Water Sci. Technol., 2016, 74(5), 1143-1154.

[68] O. Serrano-Torres, J. M. Peralta-Hernández, R. FeriaReyes, H. Jalife-Jacobo, and S. Gutiérrez-Granados, $J$. Hazard. Mater, 2016, 319, 78-83.

[69] J. D. García-Espinoza, P. Mijaylova-Nacheva, and M. Avilés-Flores, Chemosphere, 2018, 192, 142-151.

[70] G. Pérez, A. R. Fernández-Alba, A. M. Urtiaga, and I. Ortiz, Water Res., 2010, 44(9), 2763-2772.

[71] D. Mantzavinos and E. Psillakis, J. Chem. Technol. Biotechnol., 2004, 79(5), 431-454.

[72] A. M. Deshpande, S. Satyanarayan, and S. Ramakant, $J$. Environ. Eng., 2009, 135(8), 716-719.

[73] B. Wang, W. Kong, and H. Ma, 2007, 146, 295-301.

[74] I. il Balcio glu Akmehmet and M. Otker, Chemosphere, 2003, 50(1), 85-95.

[75] D. Subramaniam and A. A. Halim, 2014, 1614(1), 597602.

[76] A. Fernandes, P. Spranger, A. D. Fonseca, M. J. Pacheco, L. Ciríaco, and A. Lopes, Appl. Catal. B Environ., 2014, 144, 514-520.

[77] A. Fernandes et al., Environ. Sci. Pollut. Res., 2019, 26(1), 24-33.

[78] Y. Ge, X. C. Wang, Y. Zheng, M. Dzakpasu, J. Xiong, and Y. Zhao, 2014, 4(4), 247-258.

[79] J.M. Fontmorin, S. Huguet, F. Fourcade, F. Geneste, D. Floner, and A. Amrane, Chem. Eng. J., 2012, 195, 208217.
[80] E. Kotta, N. Kalogerakis, and D. Mantzavinos, J. Chem. Technol. Biotechnol., 2007, 82(3), 504-511.

[81] J. Vidal, C. Huiliñir, and R. Salazar, Electrochim. Acta, 2016, 210, 163-170.

[82] C. Lütke Eversloh, N. Henning, M. Schulz, and T. A. Ternes, Water Res., 2014, 48(1), 237-246.

[83] J. Radjenovic, A. Bagastyo, R. A. Rozendal, Y. Mu, J. Keller, and K. Rabaey, Water Res., 2011, 45(4), 15791586.

[84] M. Zhou, L. Liu, Y. Jiao, Q. Wang, and Q. Tan, Desalination, 2011, 277(1-3), 201-206.

[85] A. P. Buzzini, D. W. Miwa, A. J. Motheo, and E. C. Pires, Water Sci. Technol., 2006, 54(2), 207-213.

[86] M. Panizza and G. Cerisola, Environ. Sci. Technol., 2004, 38(20), 5470-5475.

[87] P. Cañizares, A. Beteta, C. Sáez, L. Rodríguez, and M. A. Rodrigo, Chemosphere, 2008, 72(7), 1080-1085.

[88] P. Verlicchi, A. Galletti, M. Petrovic, and D. BarcelÓ, J. Hydrol., 2010, 389(3-4), 416-428.

[89] B. Khaled, B. Wided, H. Béchir, E. Elimame, L. Mouna, and T. Zied, Arab. J. Chem., 2015, 12(8), 1848-1859.

[90] R. Shankar, L. Singh, P. Mondal, and S. Chand, Desalin. Water Treat., 2014, 52(40-42), 7711-7722.

[91] A. H. Sulaymon and A. H. Abbar, Electrolysis, 2012, 17.

[92] P. H. Britto-Costa and L. A. M. Ruotolo, Brazilian J. Chem. Eng., 2012, 29(4), 763-773.

[93] E. M. Abou-Taleb, M. S. Hellal, and K. H. Kamal, Water Environ. J., 2021, 35(1), 259-268.

[94] H. Monteil, Y. Pechaud, N. Oturan, C. Trellu, and M. A. Oturan, Chem. Eng. J., 2021, 404, 127048.

[95] M. Shestakova and M. Sillanpa, Rev. Environ. Sci. Bio/ Technology, 2017, 16(2), 223-238. 